Westinghouse Advanced Reactors Division

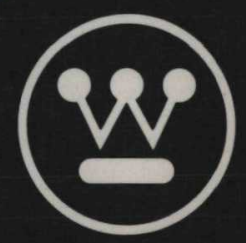




\section{DISCLAIMER}

This report was prepared as an account of work sponsored by an agency of the United States Government. Neither the United States Government nor any agency Thereof, nor any of their employees, makes any warranty, express or implied, or assumes any legal liability or responsibility for the accuracy, completeness, or usefulness of any information, apparatus, product, or process disclosed, or represents that its use would not infringe privately owned rights. Reference herein to any specific commercial product, process, or service by trade name, trademark, manufacturer, or otherwise does not necessarily constitute or imply its endorsement, recommendation, or favoring by the United States Government or any agency thereof. The views and opinions of authors expressed herein do not necessarily state or reflect those of the United States Government or any agency thereof. 


\section{DISCLAIMER}

Portions of this document may be illegible in electronic image products. Images are produced from the best available original document. 


\section{Westinghouse Electric Corporation}

Power Systems

Advanced Reactors Division

Box 158

Madison Pennsyivania 15663

March 23, 1971

WARD- 1330

U. S. Atomic Energy Commission

Technical Information

P. 0. Box 62

Oak Ridge, Tennessee 37830

Gentlemen:

SUBJECT: AEC/NYOO Contract AT(30-1)-4270, Task 3, Fast Reactor Fue] Element Development

The enclosed 135 copies of WARD-4210T3-2, "Stainless Steel Cladding Development Quarterly Progress Report for the Period Ending December 31, $1970, "$ are for recipients under the UKAEA/USAEC and EURATOM/USAEC Fast Breeder Reactor Exchange arrangement.

Very truly yours,

WESTINGHOUSE ELECTRIC CORPORATION

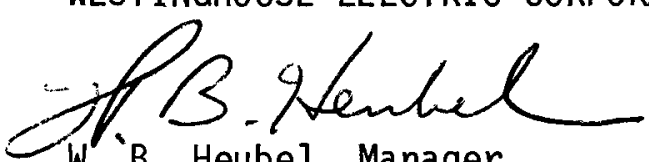

W. B, Heubel, Manager

Marketing Administration

$\mathrm{FAB} / \mathrm{mft}$

Enclosure

cc: See Attached List w/o enclosure 
Form AEC-426

$(6 / 68)$

AECM 3201

\section{U.S. ATOMIC ENERGY COMMISSION}

MAJOR CONTRACTOR'S RECOMMENDATION FOR

DISPOSITION OF SCIENTIFIC AND TECHNICAL DOCUMENT

(See Instructions on Reverse Side)
AEC REPORT NO.

WARD-4210T3-2

2. SUBJECT CATEGORY NO.

$\mathrm{UC}-25$
3. TITLE

Stainless Steel Cladding Development Quarterly Progress Report for the Period Ending December 31, 1970

4. TYPE OF DOCUMENT (Check one):

Q a. Scientific and technical report.

$\square$ b. Conference paper not to be published in a journal:

Title of conference

Date of conference

Exact location of conference

Sponsoring organization

c. Other (Specify)

5. COPIES TRANSMITTED (Check one or more applicable boxes):

[X] a. Copies being transmitted for standard distribution by AEC - DTI. (UKAEA/USAEC and EURATOM/USAEC exchange)

$\square$ b. Copies being transmitted for special distribution by AEC - DTI, per attached list.

c. Two reproducible copies being transmitted to AEC - DTI.

6. RECOMMENDED DISTRIBUTION (Check one):

[X] a. Normal handling (after patent clearance): no restraint on distribution except as may be required by the security classification.

$\square$ b. Normal handling in the U.S. (after patent clearance), but no foreign distribution.

$\square$ c. Make available only to U.S. Government agencies and their contractors.

$\square$ d. Make available only within AEC and to AEC contractors.

$\square$ e. Make available only within AEC.

$\square$ f. Make available only to those listed in item 11., below.

$\square$ g. Other (Specify)

7. RECOMMENDED ANNOUNCEMENT (Check one):

[X] Normal procedure may be followed.

$\square$ b. Recommend following announcement limitations:

8. REASON FOR RESTRICTIONS RECOMMENDED IN 6. OR 7. ABOVE:

$\mathrm{N} / \mathrm{A}$

9. PATENT CLEARANCE (Check one):

X] a. AEC patent clearance has been granted by responsible $A E C$ patent group.

b. Document has been sent to responsible AEC patent group for clearance.

10. DEFENSE INFORMATION (For classified document only. Check one):

Document a. $\square$ does $\quad$ b. $\square$ does not contain defense information other than restricted data.

11. ADDITIONAL INFORMATION OR REMARKS (Continue on separate sheet if necessary.):

None

SUBMITTED BY: NAME AND POSITION (Please print or type)

W. B. Heube1, Manager, Marketing Administration

Organization Westinghouse Electric Corporation

Advanced Reactors Division

Box 158, Madison, Pennsylvania 15663 
Who uses this Form: All AEC contractors except those specifically instructed by their AEC contract administrator to use the shorter Form AEC-427.

When to use: Submit one copy of this form with each document (except reprints of journal articles) or with each bulk shipment which is sent to AEC's Division of Technical Information (DTI) in accordance with the requirements of AEC Manual Chapter 3201. The Chapter specifies that preprints and manuscripts of journal articles, and manuscripts of conference papers which are to be published in a journal in substantially the same form and detail should not be sent to DTI. Reprints of journal articles may be sent to DTI, but no transmittal form should be used with reprints.

Where to send: Forward this form and the document(s) to:

USAEC - Technical Information

P. O. Box 62

Oak Ridge, Tennessee 37830

Item instructions:

Item 1. The first element in the number shall be a code to be determined as follows: (a) The responsible field office may request DTI approval of a unique code for a contractor, e.g., BNL, BMI, ORNL, etc.; (b) A program division may request DTI approval of a unique code for a program or series of reports, e.g., PNE, VUF, etc.; (c) An operations office may instruct a contractor to use the code approved for the operations office, i.e., NYO, COO, ORO, IDO, SRO, SAN, ALO, RLO, NVO; and (d) Program divisions shall use the code WASH for reports which they themselves prepare.

The code shall be followed by a sequential number, or by a contract number plus a sequential number, as follows: (a) Contractors or programs with unique codes may complete the report number by adding a sequential number to the code, e.g., ORNL-101, ORNL-102, etc.; or PNE-1, PNE-2, etc.; or they may add the identifying portion of the contract number and a sequential number, e.g., $A B C-2105-1$, ABC-2105-2, etc.; (b) Contractors using the operations office code shall complete the report number by adding the identifying portion of the contract number and a sequential number, e.g., NYO-2200-1, NYO-2200-2, etc.; and (c) Program divisions using the WASH code shall complete the report number by adding a sequential number which they request from DTI's Document Management Branch in Oak Ridge.

Item 2. Insert the appropriate subject category from TID-4500 ("Standard Distribution for Unclassified Scientific and Technical Reports") or M-3679 ("Standard Distribution for Classified Scientific and Technical Reports") for both classified and unclassified documents, whether or not printed for standard distribution.

Item 3. Give title exactly as on the document itself unless title is classified. In that case, omit title and state "classified title" in the space for item 3.

Item 4. If box $c$ is checked, indicate type of item being sent, e.g., thesis, translation, computer program, etc.
Item 5. a. The number of copies specified for the appropriate category or categories in M-3679 or TID -4500 shall be forwarded to DTI for distribution.

b. If box $\mathrm{c}$ is checked, at least one copy shall be original ribbon or offset and be completely legible. A clear carbon copy is acceptable as a second reproducible copy.

Item 6. If box a is checked for an unclassified document, it may be distributed (after patent clearance) to addressees listed in TID-4500 for the appropriate subject category, to AEC depository libraries in the U.S. and abroad, to the Clearinghouse for Federal Scientific and Technical Information for sale to the public, and to authorized foreign recipients.

If box $\mathrm{a}$ is checked for a classified document, it may be distributed to addressees listed in M-3679 for the appropriate subject category.

If a box other than a is checked, the recommended limitation will be followed if not inconsistent with AECM-2104, "Information for Official Use Only", and unless DTI receives other instructions from the responsible AEC program division.

Box g may be checked in order to specify special instructions, such as "Make available only as specifically approved by the program division", etc.

Item 7. a. Announcement procedures are normally determined by the distribution that is to be given a document. If box $a$ or $b$ in item 6 is checked for an unclassified document, it will normally be listed in DTI's "Weekly Accessions List of Unlimited Reports" (TID-4401) and may be abstracted in "Nuclear Science Abstracts" (NSA).

A classified document, or an unclassified document for which box c, $d$, e, $f$, or $g$ is checked, will normally be listed in DTI's "Weekly Accessions List of Limited Distribution Reports" (TID-4400) and may be abstracted in "Abstracts of Limited Distribution Reports” (ALDR).

b. Check $7 \mathrm{~b}$ if the normal announcement procedures described in $7 \mathrm{a}$ are not appropriate and indicate recommended announcement limitations.

Item 8. If a box other than a is checked in item 6 , or if $7 \mathrm{~b}$ is checked, state reason for the recommended restriction, e.g., "preliminary information", "prepared primarily for internal use", etc.

Item 9. It is assumed that there is no objection to publication from the standpoint of the originating organization's patent interest. Otherwise explain in item 11 .

Item 10. The purpose of this item is to determine whether a given classified document can be distributed to access permittees. If box $a$ is checked, it cannot be made available to them (Code of Federal Regulations, 10 CFR, Part 35, subpart 25.6); if box b is checked, DTI will determine whether or not to make it available.

Item 11. Use this space if necessary to expand on answers given above, e.g., item $6 f$ and item 9 .

Item 12. Enter name of person to whom inquiries concerning the recommendations on this form may be addressed. 


\title{
DISTRIBUTION LIST
}

\author{
NYOO - Manager \\ $\mathrm{RDT} / \mathrm{HQ}$ - Director \\ RDT/HQ - Asst. Dir., Reactor Engineering \\ RDT/HQ - Asst. Dir., Project Management \\ RDT/HQ - Asst. Dir., Nuclear Safety \\ RDT/HQ - Asst. Dir., Reactor Technology \\ RDT/HQ - LMFBR Program Manager \\ RDT/HQ - Chief, Fuels and Material Branch \\ RDT/HQ - Chief, Fuels Engineering Branch \\ RDT/HQ - Chief, Coolant Chemistry Branch \\ RDT - Asst. Dir., Pacific Northwest Programs \\ RDT - Sr. Site Rep. at Westinghouse \\ RDT - Sr. Site Rep. at ANL \\ HEDL - Vice President and Technical Director \\ ANL - Director, LMFBR Program Office \\ RDT/HQ - Asst. Dir., Program Analysis \\ $A E C / H Q$ - Director, Division of International Affairs
}


This report was prepared as an account of work

sponsored by the United States Government. Neither

the United States nor the United States Atomic Energy

Commission, nor any of their employees, nor any of

their contractors, subcontractors, or their employees,

makes any warranty, express or implied, or assumes any

legal liability or responsibility for the accuracy, com-

pleteness or usefulness of any information, apparatus,

product or process disclosed, or represents that its use

would not infringe privately owned rights.

STAINLESS STEEL CLADDING DEVELOPMENT

QUARTERLY PROGRESS REPORT

FOR THE PERIOD ENDING DECEMBER 31, 1970

THIS DOCUMENT CONFIRMED AS

UNCLASSIFIED

DIVISION OF CLASSIFICATION

BY OHlahar famh

DATE 411517

Approved by:

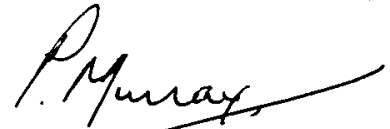

P. Murray

Project Manager

Prepared for the U.S. Atomic Energy Commission

Division of Reactor Development and Technology

Under Contract No. AT(30-1) -4210, Task 3, Subtask A.

Submitted to AEC/NYOO in February 1971

Westinghouse Electric Corporation

Advanced Reactors Division

P. 0. Box 158

Madison, Pennsylvania 15663 
This report was prepared as an account of work sponsored by the United States Government. Neither the United States nor the United States Atomic Energy Commission, nor any of their employees, nor any of their contractors, subcontractors, or their employees, makes any warranty, express or implied, or assumes any legal liability or responsibility for the accuracy, completeness or usefulness of any information, apparatus. product or process disclosed, or represents that its use would not infringe privately owned rıghts.

Printed in the United States of Amerıca Avallable from

National Technical Information Service Springfield, Virginia 22151

Prıce: Prınted Copy $\$ 3.00 ;$ Mıcrofıche $\$ 0.95$ 


\section{TABLE OF CONTENTS}

1

SSDA -110

SSDA -210
Introduction.............................

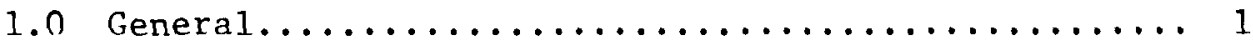

2.0 Summary of objectives.....................

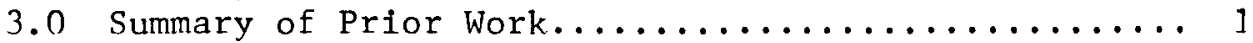

4.0 Summary of Current Progress................. 2

Project Administration..................... 5

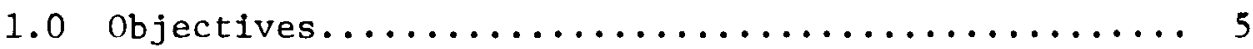

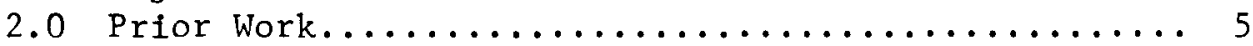

3.0 Current Progress........................ 5

Evaluation of Austenitic Stainless Steel cladding......7 7

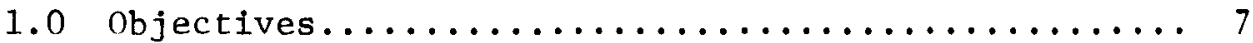

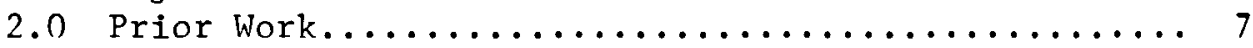

3.0 Current Progress........................ 8

3.1 Procurements and Handling.............. 8

3.2 Nondestructive Testing................ 9

3.2.1 Eddy Current.................. 9

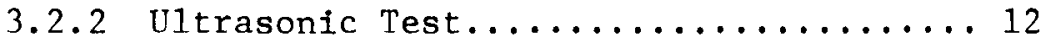

3.2 .3 Air Gage Equipment.............. 12

3.2 .4 Replica Procedure............... 12

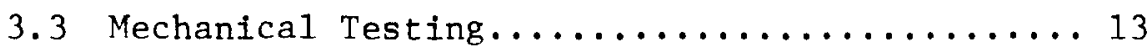

3.3.1 Biaxial Stress Rupture - Vacuum Melted Steels Task......................13

3.3.2 Biaxial Stress Rupture Testing in

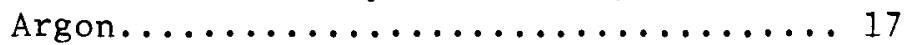

3.3.3 Uniaxial Creep................. 22

3.4 Post-Test Specimen Characterization - Biaxial

Stress Rupture Morphology Correlation........ 22

3.5 Post Stress Rupture Specimen Characterization Vacuum Melted Steels Task............... 24

3.6 Post-Test Metallographic Characterization..... 29

3.6.1 Vacuum Melted Steels Task............ 29

3.6.2 Annealed Plug Drawn Specimen..........29

3.6.3 Annealed Planetary Swaged specimen...... 33

3.6.4 Cold Worked, Plug Drawn Specimen - High

Temperature.................. 33 


\section{CONTENTS (CONTINIIED)}

3.6.5 Cold Worked, P1ug Drawn Specimen - Low Temperature................... 34

3.6.6 Cold Worked, Planetary Swaged Specimen.. 34

3.6.7 Future Plans.................. 34

3.6.8 Effects of Cold Work on Rupture Life... 36

3.6 .9 Reports and Papers.................... 36

3.7 Literature Survey................. 36

3.7.1 Artificial Defect Study at Genera1

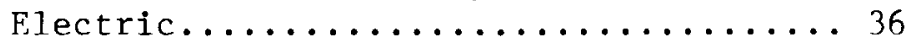

3.7.2 Natural Defect Study at General Electric........................... 37

3.7.3 Other Studies at General Electric..... 37

3.7 .4 Studies at WADCO.................. 37

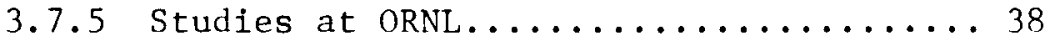

3.7.6 Studies at Argonne National Laboratory.. 39

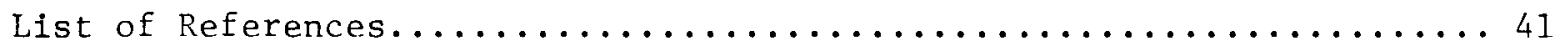




\section{LIST OF FIGIJRES}

Figure

Nondestructive Testing (NDT) Traces....................1]

Biaxial Stress Rupture Results for Plug Drawn, Type 316 Stainless Steel Tubing Fabricated by Three Vacuum Melting Practices................................... 15 less Steel, Fabricated by Plug Drawing and by Planetary

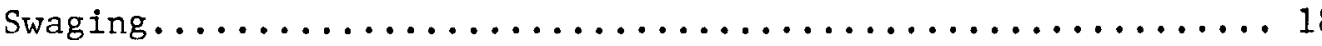

5 Biaxial Stress Rupture Results for 20 Percent Cold-Worked and Annealed Type 316 Stainless Steel Tubing................ 19

Biaxial Stress Rupture Results for Planetary Swaged, Type 316

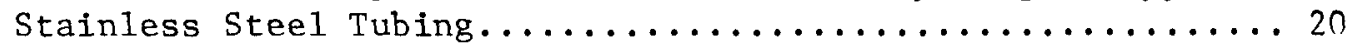

Plug Drawn Tubing - Strain Profiles for Post-Test, Stress Rupture Specimens............................. 25

Planetary Swaged Tubing - Strain Profiles for Post-Test, Stress Rupture Specimens........................ 26

Wall Thinning Measurements, $\Delta t / t_{o}$, Versus Angle Relative to Rupture Area for Plug Drawn, Fine Grained Type 316 Stainless

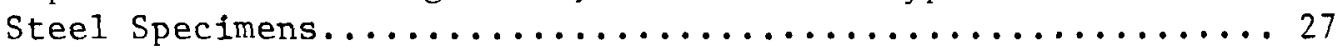

Wa1l Thinning Measurements, $\Delta t / t_{0}$, Versus Angle Relative to Rupture Area for Planetary Swaged, Coarse Grained Type 316 Stainless Steel Specimens...................... 28

Post-Test Stress Rupture Specimen - Plug Drawn, Annealed, Lot 42403, Grain Size 8 - Rupture Time $2424 \mathrm{hr}$, Hoop Stress

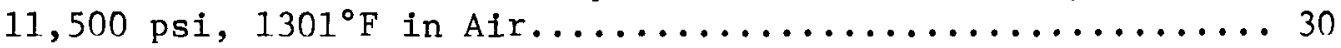

12 Post-Test Stress Rupture Specimen - Planetary Swaged, Annealed, Lot 49194, Grain Size 6 - Rupture Time $2494 \mathrm{hr}$, Hoop Stress 11,800 psi, $1300^{\circ} \mathrm{F}$ in $\operatorname{Air} \ldots \ldots \ldots \ldots \ldots \ldots \ldots \ldots \ldots$

13 Post-Test Stress Rupture Specimen - Plug Drawn, 20 Percent Cold Worked, Lot 42402, Grain Size 9 - Rupture Time $2368 \mathrm{hr}$,

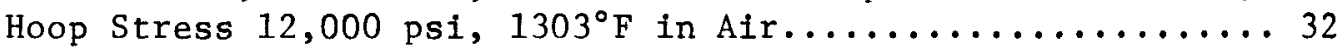


14 Post-Test Stress Rupture Specimen - P1ug Drawr, 20 Percent Cold Worked, Lot 42402, Grain Size 9 - Rupture Time $2124 \mathrm{hr}$, Hoop Stress 24,000 psi, $1214^{\circ} \mathrm{F}$ in Air................... 35

\section{LIST OF TABLES}

2 Biaxial Stress Rupture Data for Type 316 Stainless Steel

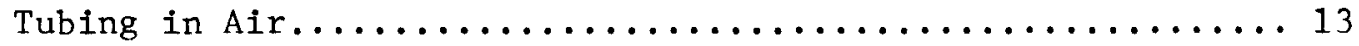

3 Biaxial Stress Rupture Data for Type 316 Stainless Stee1

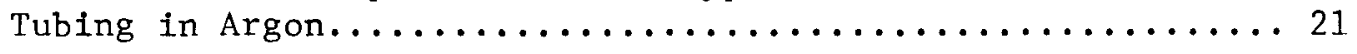

4 Stainless Steel Biaxial Stress Rupture Fracture Classification - $1300^{\circ} \mathrm{F}$ Nominal Temperature $\left( \pm 15^{\circ} \mathrm{F}\right)$ Air Atmosphere. 


\section{SECTION 1}

INTRODUCTION

\subsection{GENERAL}

This is the tenth quarterly progress report and covers the work performed during the second quarter of FY-1971.

\subsection{SUMMARY OF OBJECTIVES}

This project is focused on the short term, and is concerned with steps to improve commercially available Type 316 austenitic stainless steels for use as cladding in LMFBR fuel rods. The overall project objective is to determine the influence of structure on mechanical properties of Type 316 austenitic stainless steel so that optimum specifications, which will assure maximum performance under LMFBR service conditions, can be selected.

The importance of structure on mechanical properties has been well demonstrated in the published literature. For example, in one series of experiments, [1]prestraining of Type 316 austenitic stainless steel, followed by a specific heat treatment to produce carbide precipitation, decreased the minimum creep rate at temperatures of interest to LMFBR by as much as a factor of 250, and increased creep rupture life by as much as a factor of 25 .

Initially in the cladding development program, a survey will be made to determine tubing material property and microstructural variability based on procurement of tubing under an existing FFTF specification. This specification will be used as a starting point. Materials with various fabrication histories will be procured and evaluated in both the as-fabricated condition and after post-fabrication heat treatment. The relations between mechanical properties and structure will be investigated.

It is anticipated that this first phase of the cladding program will culminate at the end of FY-1972 with a definition of the most desirable mechanical and microstructural properties in austenitic stainless steel, to maximize the strength and ductility of the material under the most limiting LMFBR service conditions.

\subsection{SUMMARY OF PRIOR WORK}

All work related to the present investigations and performed prior to the present period has been fully reported in:

\footnotetext{
WARD-3791-26 "Stainless Steel Cladding Development Quarterly Progress Report for the Period Ending September 30, 1968."
} 


\begin{abstract}
WARD-3791-29 "Stainless Steel Cladding Development Quarterly Progress Report for the Period Ending December 31, 1968."

WARD-3791-35 "Stainless Steel Cladding Development Quarterly Progress Report for the Period Ending March 31, 1969."

WARD-3791-41 "Stainless Steel Cladding Development Quarterly Progress Report for the Period Ending June 30, 1969."

WARD-4135-2 "Stainless Steel Cladding Development Quarterly Progress Report for the Period Ending September 30, 1969."

WARD-4135-5 "Stainless Steel Cladding Development Quarterly Progress Report for the Period Ending December 31, 1969."

WARD-4135-9 "Stainless Steel Cladding Development Quarterly Progress Report for the Period Ending March 31, 1970."

WARD-4135-12 "Stainless Steel Cladding Development Quarterly Progress Report for the Period Ending June 30, 1970."

WARD-4135-14 "Stainless Steel Cladding Development Quarterly Progress Report for the Period Ending September 30, 1970."
\end{abstract}

\title{
4.0 SUMMARY OF CURRENT PROGRESS
}

Under Task SSDA-110, project administration and day-to-day liaison with the AEC continued.

Under Task SSDA-210, the major activities during the report period were directed to the completion of the Vacuum Melted Steels Task and preparation for the Defects Evaluation Task.

Six additional long-term, stress rupture tests were completed for the Vacuum Melted Steels Task. Several additional long-term tests, required to complete the program, are in progress.

Post-test specimen characterizations using strain profile measurements, local wall thickness reductions, rupture morphology, and metallography were continued.

Long term $1300^{\circ} \mathrm{F}$, air atmosphere, stress rupture tests of both plug drawn and planetary swaged Type 316 stainless steel tubing have shown that for hoop stresses below about 12,000 psi, annealed tubing has both longer stress rupture life and greater rupture ductility than 20 percent cold worked tubing.

Correlation of rupture morphology with twelve combinations of material variables and with stress rupture conditions has shown that rupture morphology is influenced strongly by the level of cold work, the grain size, and to lesser extent by the fabrication method and melting practice. For a given material there appears to be a stress level below which only 
pinhole rupture is observed and above which mixed-type ruptures occur.

A topical report covering the Vacuum Melted Steels Program is being written. Completion is expected during April 1971.

A paper entitled "Development of Type 316 Stainless Steel Tubing for LMFBR Fuel Element Cladding," by T. R. Padden, W. E. Ray, H. J. Snyder, and K. C. Thomas, was presented at the Winter Meeting of the ANS in Washington, D. C.

The stainless steel tubing ordered from Superior Tube Company for the Defects Evaluation Task is scheduled to be shipped in two parts, the first on January 8, 1971 and the balance on January $28,1971$.

Electro-discharge machined standards for eddy current and ultrasonic testing have been procured from two manufacturers.

An order has been placed for wall thickness and eccentricity standards to be fabricated from Carpenter heat number 91695, double vacuum melted, Type 316 stainless steel. These standards, in addition to the notch standards, will allow tubing characterization using eddy current, ultrasonic, and air gage techniques.

Preliminary NDT measurements were made on ten tubes of ARD double vacuum melted, 20 percent cold worked tubing to calibrate the NDT equipment, define procedures, and to select a length of tubing for the preliminary stress rupture tests on intentionally defected specimens.

Statistical analysis of the eddy current response to standard defects of various sizes, orientation, and locations has been initiated.

Three furnaces have been converted to argon atmosphere stress rupture testing facilities; conversion of additional furnaces is in progress. To date, five runs have been completed to test these units.

A uniaxial creep unit is now operational, using a microscope to measure deformation on a platinum gage attached to the specimen; this method is similar to that used by Conway and Flagella[2]. Creep measurements are being made on lot number 42402, 20 percent cold worked, vacuum melted Type 316 stainless steel tubing. The test conditions are $1200^{\circ} \mathrm{F}$ and $15,000 \mathrm{psi}$ stress in vacuum. A second unit is nearing completion in which a test at $1200^{\circ} \mathrm{F}$ and 12,000 psi is planned.

A surface replica procedure was developed for nondestructive evaluation of surface defects; the procedure was based on materials information obtained in a personal communication with J. Ryden (WADCO). Although there is still some difficulty in removing replicas from the internal surface of tubing, an acceptable replica has been made of the full inside surface of a 15-inch length of tubing. This procedure will be used in the next report period to evaluate internal surface defects and to measure the internal electrodischarge machined notches in the nondestructive testing standards.

An immersion density facility and procedure are being developed to measure density of tubing to better than 0.02 percent. The objective of this effort 
is to determine density changes as a function of stress and temperature during stress rupture. 


\section{SSDA-110 PROJECT ADMINISTRATION}

F. A. Brassart, W. B. Heubel, and P. Murray

\subsection{OBJECTIVES}

The objectives of this task are to assure that the project is successfully completed, on schedule, within budget, and to the satisfaction of the Atomic Energy Commission (AEC); to assure compliance with contracted obligations; and to coordinate this project with other AEC-sponsored and Westinghouse-sponsored LMFBR development projects.

Overall project direction and day-to-day administration will be provided under this task. Plans and controls will be established and maintained, periodic reviews will be held with the $\mathrm{AEC}$, correspondences and reports will be coordinated, and day-to-day technical and administrative liaison with the AEC will be provided.

\subsection{PRIOR WORK}

Schedule 189a/Work Plan for FY-1971 was prepared and submitted to the New York Operations Office. Technical work has continued on the basis of the work plan. The project is divided into the following tasks for FY-1971 administrative control.

\section{SSDA-110 Project Administration \\ SSDA-210 Evaluation of Austenitic Stainless Steel Cladding}

\subsection{CURRENT PROGRESS}

The quarterly progress report, WARD-4135-14, for the period ending September 30,1970 was prepared and distributed. 
SSDA-210 EVALUATION OF AUSTENITIC STAINLESS STEEL CLADDING

T. R. Padden, W. E. Ray, H. J. Snyder, E. J. Tarby, and K. C. Thomas

\subsection{OBJECTIVES}

The objective of this task is to characterize in detail, by microstructural analysis, chemical analysis, and mechanical property testing, thin-wall stainless steel tubing, fabricated under carefully controlled commercial practice. This information will be used to:

1. Enhance the understanding of the effect of fabrication processes and resulting structure on the properties of thin-wall tubing.

2. Provide out-of-reactor data required to predict and improve swelling behavior and strain limits of cladding in LMFBR environments.

The objective of a supplementary weldability investigation is to determine the effect of the degree of cold working on the weldability of Type 316 stainless steel tubing.

\subsection{PRIOR WORK}

During the first year (FY-1969), a test program was prepared and initiated with air melted, annealed Type 316 stainless steel tubing, 0.300-inch OD at three wall thicknesses $(0.010,0.012$, and $0.014-i n c h)$, and 0.250 -inch OD by 0.016 -inch wall. Extensive biaxial burst testing at 850, 1000, 1200, and $1300^{\circ} \mathrm{F}$ and chemical and microstructural evaluation of the tubing were performed, and biaxial stress rupture testing was initiated. This part of the program was completed during the second year and included a thermal aging study of several lots of the air melted materials aged for times up to 5000 hours.

The program was extended to a systematic investigation of vacuum melted, Type 316 stainless steel, plug drawn tubing. Twelve lots of tubing ordered during FY-1969 and received at the beginning of FY-1970 were extensively tested and characterized during FY-1970 and the beginning of FY-1971. This tubing included the twelve combinations of three vacuum melting practices, two grain sizes and the two finished conditions ( 20 percent cold worked and solution annealed). In addition, two lots of planetary swaged tubing were procured and included in the test program.

General characterization of the vacuum melted tubing has been completed, including chemical analysis, light microscopy, and hardness measurements.

Comprehensive structural characterization was completed for two of the plug 
drawn lots and the two planetary swaged lots, all fabricated from doublevacuum-melted steel. These characterizations included transmission and scanning electron microscopy, electron and $x$-ray diffraction, and texture analysis by pole figures. The as-received cold worked, plug drawn lot was also characterized by electron probe analysis.

Biaxial tensile testing at room temperature and five elevated temperatures was completed for the 14 lots of vacuum melted steel tubing. Results were compared and evaluated for the effects of the independent variables on the properties of tubing.

Extensive biaxial stress rupture testing was performed at $1300^{\circ} \mathrm{F}$ in air, and selected tests conducted of $1200^{\circ} \mathrm{F}$. Preliminary evaluations were made at various stages of the test program. Long term tests are still in progress.

Post-test classification of stress ruptured specimens according to rupture microphology, material variables, and test conditions continued throughout the test program.

Strain profile and wall thickness measurements were made of selected posttest specimens along with metallographic evaluations.

A summary of the vacuum melted steels task was initiated in preparation for issuance of a topical report.

In preparation for the "Defects Evaluation Task", included in the work program for the current fiscal year, nondestructive test equipment was procured and installed, and preliminary testing was initiated.

Tubing required for this defects evaluation test program was ordered from Superior Tube Company. This order consists of 23 lots and sublots, representing various combinations of fabrication procedures, finishing steps, and acceptance tests. The order was specified such that three severity levels of naturally occurring defects should be obtained.

\subsection{CURRENT PROGRESS}

\subsection{Procurements and Handling}

The inftial shipment of stainless steel tubing, ordered from Superior Tube Company for the Defects Evaluation Task, is scheduled for January 8, 1971, and the balance on January 28, 1971. This order is being fabricated from ARD double vacuum melted, Type 316 stainless steel, heat number 91695. Various combinations of fabrication procedures and finishing steps are included in this order. By special arrangement with Superior Tube Company, the order includes selected sublots which have been ultrasonically tested to three notch standards. This will enable three defect levels to be established for naturally occurring defects.

A nondestructive test (NDT) standard[3] containing twelve electro-discharge machined notches was procured from Metcut Research Associates, Inc. for 
comparison with the similar standard procured previously from Kenmar Corporation.

An order has been placed for wall thickness and eccentricity standards to be fabricated from Carpenter heat number 91695, double vacuum melted Type 316 stainless steel. These standards, in addition to the notch standards, will allow tubing characterization using eddy current, ultrasonic, and air gage techniques.

Twenty-one feet of 20 percent cold worked Type 316 stainless steel tubing, having a 0.223 -inch ID and 0.010 -inch wall were provided for the WSA-5

fuel pins.

Quotations were procured for reactor grade Type 316 stainless steel tubing for the Mark B-6 subassembly capsules.

Two-hundred-eighty-four feet of Type 304 stainless steel tubing, having a 0.3125 -inch $O D$ and a 0.035 -inch wall were purchased to serve as shipping containers for the WSA-3 fuel pins.

The NDT and wall thickness charts were received from WADCO for the PNL tubing, procured for the two 37-pin assemblies, WSA-3 and WSA-4.

\subsection{Nondestructive Testing}

Nondestructive characterization of Type 316 stainless steel cladding was infitiated with ten tube lengths from lot number 42402, ARD, VM (IVCEV), plug drawn tubing and an electro-discharge machined (EDM) 12-notch standard made from the same lot to calibrate the NDT equipment and define procedures. The tubing had been fabricated from double vacuum melted, heat number 91695 , and finished in the 20 percent cold worked condition with ASTM grain size 9. The material had been purchased to ARD specification ARD-AMMA-001[4]permitting both pickling and surface polishing after the last pass. The ultrasonic test standards specified to set maximum defect levels in the lot had been a radial hole having a 0.006-inch diameter and 0.01275-inch depth, and a longitudinal notch having a width of $0.004-$ inch, a depth of $0.002-i n c h$, and a length of 0.250-inch. Microstructural and diffraction characterization results for this tubing lot have been given in previous quarterly reports. $[5,6,7,8,9]$

\subsubsection{Eddy Current}

To first establish sensitivity levels of the eddy current equipment, traces, using automatic feeding, were made of the 12-notch electro-discharge machined (EDM) standard [3] which contained smaller defects than used in the tubing specifications for lot number 42402.[4] This standard contained ID and OD notches, oriented both longitudinally and circumferentially. The sizes were $0.002-$ inch wide by 0.030 -inch long, and 0.0005 -inch, 0.0010 -inch, and 0.0015 -inch deep. 
Figure 1 illustrates an eddy current trace for the standard. All twelve notches indicated eddy current responses; even the shallowest (0.0005-inch) defects (numbers 5, 7,10 and 12 ) are readily dectectable. The sensitivity of the eddy current unit appears to be quite satisfactory, especially considering that this standard was made from a tubing lot (number 42402) which had been surface polished.

The ten tube lengths from lot number 42402, purchased to the less stringent NDT specifications than the demonstrated sensitivity level were then tested against this standard. Defect indications greater than the minimum indications in the standard were observed in each tube. The frequency of occurrence for each is included in Table 1. Further evaluations of this tubing lot is in progress to locate small naturally occurring defects of various sizes for the Defects Evaluation Task.

\begin{tabular}{|c|c|c|}
\hline Tube No. & $\begin{array}{l}\text { Number of Eddy Current Defect* } \\
\text { Indications Greater Than the } \\
0.0005-i n \text {. Notch Standard }\end{array}$ & $\begin{array}{l}\text { OD Air Gage } \\
\text { Measurement Range (in.) }\end{array}$ \\
\hline 1 & 12 & $0.2304-0.2316$ \\
\hline 2 & 4 & $0.2304-0.2315$ \\
\hline 3 & 7 & $0.2306-0.2312$ \\
\hline 4 & 19 & $0.2306-0.2312$ \\
\hline 5 & 4 & $0.2304-0.2312$ \\
\hline 6 & 4 & $0.2305-0.2314$ \\
\hline 7 & 4 & $0.2305-0.2313$ \\
\hline 8 & 7 & $0.2305-0.2311$ \\
\hline 9 & 9 & $0.2302-0.2311$ \\
\hline 10 & 2 & $0.2305-0.2313$ \\
\hline \multicolumn{3}{|c|}{$\begin{array}{l}\text { * Tubing was inspected using standards having notches } 0.030 \text {-inch- } \\
\text { long, } 0.002-\text { inch-wide, and } 0.0005-\text { inch to } 0.0015-\text { inch deep. } \\
\text { Tubing was purchased to specification having notch standards } \\
0.250 \text {-inch long, } 0.005-\text { inch wide, and } 0.002-\text { inch deep, together } \\
\text { with a radial hole } 0.006 \text {-inch diameter and } 0.01275-i n c h \text { deep. }\end{array}$} \\
\hline
\end{tabular}

In addition to the preliminary tests, a total of 100 runs have been made on the ARD lot number 42402 notch standard with the eddy current equipment. These runs will be used to provide the statistical evaluation of the equipment, to determine run-to-run and long-term variations. Statistical charts will be prepared containing mean values and 95 percent confidence levels for the notch standard. These notch standard results will then be used to quantitatively characterize the tubing that will be used in the Defect Evaluation Task. 
D
ป̀
á EDDY CURRENT TRACE OF TYPE 316 STAINLESS STEEL TUBING (Lot 42402) 12 NOTCH STANDARD

(All notches $0.030-i n$. long and $0.002-i n$. wide)

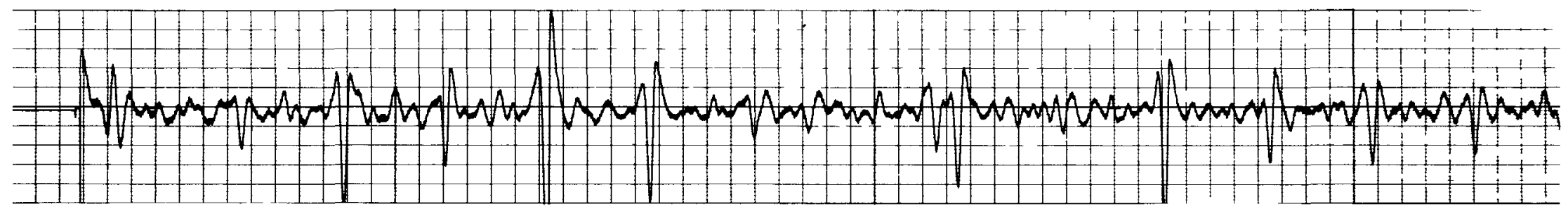

$\begin{array}{lccccccccccccc}\text { NOTCH NO. } & 12 & \text { II } & 10 & 9 & 8 & 7 & 6 & 5 & 4 & 3 & 2 & 1 \\ \text { DIRECTION } & \text { A } & \text { A } & \text { A } & \text { A } & \text { C } & \text { C } & \text { C } & \text { C } & \text { A } & \text { C } & \text { A } & \text { C } \\ \text { DEPTH (mils) } & 0.5 & 1.5 & 0.5 & 1.5 & 1.5 & 0.5 & 1.5 & 0.5 & 1.0 & 1.0 & 1.0 & 1.0\end{array}$

AIR GAGE TRACE OF TYPE 3 I 6 STAINLESS STEEL TUBING

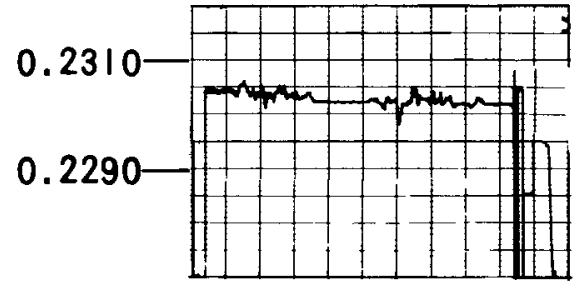

Figure 1. Nondestructive Testing (NDT) Traces (70 Percent Origina1) 


\subsubsection{Ultransonic Test}

A similar statistical evaluation has been initiated on the ultrasonic equipment using the ARD lot number 42402 notch standard. Delay of this part of the program occurred due to a circuitry failure. The equipment has been returned for repair and is scheduled for operation in January 1971.

\subsubsection{Air Gage Equipment}

A mechanical drive unit is being constructed at ARD and will be installed in January 1971. This will allow automatic transport of the tubing for precise $O D$ and ID air gage measurements.

During construction of the mechanical transport system, preliminary tests were run using hand feeding, whereby OD measurements were made and recorded with air gage equipment. These preliminary $O D$ air gage measurements for the 10 tube lengths previously described are included in Table 1 and an example of an air gage trace is included in Figure 1. The OD sensitivity appears to be about $0.0001-i n c h$, but the measured values were slightly higher than the dimensions certified by the manufacturer for this lot (0.2304 to 0.2310 -inch). The discrepancy is probably the result of the hand feeding during these preliminary tests. The air gage measurement will be repeated when the mechanical transport system is operational.

\subsubsection{Replica Procedure}

A plastic replica procedure is being developed to:

1. Evaluate ID surface defects in stainless steel tubing

2. Correlate microscopy observations with NDT results

3. Measure ID notches on NDT standards

4. Make permanent records of tubing surfaces prior to mechanical test.

The replicas are made with Chem Sol PK 4706 (suggested by J. Ryden, WADCO). This material is a polyvinyl chloride (PVC) dispersion which gels at $120^{\circ} \mathrm{F}$, and cures to a tough but flexible solid at 325 to $375^{\circ} \mathrm{F}$. The procedure used in this laboratory for ID replicas is to slip cast a hollow cylindrical layer on the inside of the tube. The cast PVC 1iquid is then gelled and cured by resistance heating the tube. Removal is accomplished in two steps: the replica is first loosened by collapsing the PVC film with air pressure; and then slowly pulled out of one end of the tube.

Thus far the ID replica procedure has been applied to tubing up to 15 inches in length. Some difficulty is still experienced with the stripping step however. Correction of this difficulty is in progress. 
Replicas of short lengths of tublng could be cured conviently in an oven, but for longer tubes, direct resistance heating of the stainless steel tube was found much more satisfactory. An a-c power supply was built which is capable of uniformly heating five feet of Type 316 stainless steel tubing $\left(0.230\right.$-inch OD by 0.200 -inch ID) to the curing temperatures ( 350 to $375^{\circ} \mathrm{F}$ ). A current of 25 to 27 amps is required for this size tubing.

The replica material appears to be satisfactory for the applications. The resolution of fine detail is sufficient for examination at $1000 \mathrm{X}$ with a light microscope, and dimensional faithfulness of replicas of EDM notches appears to be good to about one percent relative. For example, the length of an EDM notch measured directly was 0.0305-inch and measured from a replica was 0.0302-inch.

\subsection{Mechanical Testing}

\subsubsection{Biaxial Stress Rupture - Vacuum Melted Steels Task}

The results from six biaxial stress rupture tests in air, completed during the report period, are given in Table 2. These and several other tests in progress will complete the mechanical tests planned for the Vacuum Melted Steels Task.

\begin{tabular}{|c|c|c|c|c|c|c|c|}
\hline \multicolumn{8}{|c|}{$\begin{array}{c}\text { Table 2. Biaxial Stress Rupture Data For } \\
\text { Type } 316 \text { Stainless Steel Tubing in Air }\end{array}$} \\
\hline Lot & $\begin{array}{l}\text { Material } \\
\text { Condition }\end{array}$ & $\begin{array}{l}\text { Wall } \\
\text { Dimension } \\
\text { (in.) }\end{array}$ & $\begin{array}{l}\text { Nom. } \\
\text { Temp. } \\
\left({ }^{\circ} \mathrm{F}\right)\end{array}$ & $\begin{array}{l}\text { Test } \\
\text { Temp. } \\
\left({ }^{\circ} \mathrm{F}\right)\end{array}$ & $\begin{array}{c}\text { Stress } \\
\text { (ksi) }\end{array}$ & $\begin{array}{l}\text { Rupture } \\
\text { Time } \\
\text { (hr) }\end{array}$ & $\begin{array}{c}\text { Rupture } \\
\text { Type }\end{array}$ \\
\hline 42398 & IV-20\% CW-FG & 0.015 & 1300 & 1297 & 14 & 1369.1 & 1 \\
\hline 42404 & IVCEV-20\% CW-CG & 0.015 & 1200 & 1195 & 28 & 4321.9 & 1 \\
\hline 42402 & IVCEV-20\% CW-M & 0.015 & 1300 & 1288 & 13 & 1661.3 & 1 \\
\hline 42394 & CEV-20\% CW-FG & 0.015 & 1300 & 1313 & 14 & 852.0 & 1 \\
\hline 42394 & CEV-20\% CW-FG & 0.015 & 1200 & 1193 & 30 & 1683.9 & 1 \\
\hline 49194 & IVCEV-PS-ANN-CG & 0.015 & 1300 & 1300 & 11.8 & 2493.9 & 1 \\
\hline 1. & Pinhole & $\begin{array}{l}\mathrm{CW}-\mathrm{Col} \\
\mathrm{ANN}-\mathrm{An} \\
\mathrm{FG}-\mathrm{Fin} \\
\mathrm{CG}-\mathrm{Coa}\end{array}$ & $\begin{array}{l}\text { d Worke } \\
\text { nealed } \\
\text { e Grair }\end{array}$ & & \multicolumn{3}{|c|}{$\begin{array}{l}\text { IV - Induction Vac. } \\
\text { IVCEV - Consumable Elec. } \\
\text { Plus Induction Vac. }\end{array}$} \\
\hline
\end{tabular}


Figures 2 through 6 are plots of air atmosphere biaxial stress rupture results obtained to date from seven tubing lots, representing partial comparisons of some of the variables being tested. The variables include three vacuum melting practices, plug drawing, planetary swaging, fine and coarse grain size, as well as both annealed and 20 percent cold worked conditions. The data were obtained at 1200 and $1300^{\circ} \mathrm{F}\left(+15^{\circ} \mathrm{F}\right)$, and normalized to the nominal temperatures by means of the Chitty-Duval correlation. Data from tests in static sodium are also included in one plot. [10]

The ARD data obtained in air at $1200^{\circ} \mathrm{F}$ from 20 percent cold worked, plug drawn tubing and the AI data obtained at $1200^{\circ} \mathrm{F}$ in static sodium for 10 to 15 percent cold worked, Type 316 steel are given in the top two curves of Figure 2 .

The ARD tubing tested in air compares very favorably with the AI tubing tested in sodium. The differences which are observed in the stress rupture results from these two materials (the higher stress rupture strength for the ARD tubing and the break in its rupture curve) are the expected differences resulting from a higher level of cold work, based on the interpretations of other ARD results.

The lower three curves in Figure 2 are for $1300^{\circ} \mathrm{F}$ ARD data. These three curves compare three vacuum melting practices, for one set of fabrication conditions, namely fine grain sized, plug drawn tubing in the 20 percent cold worked condition. The double vacuum melted lot of tubing has slightly better stress rupture properties than the induction vacuum melted lot, and significantly better properties than consumable electrode vacuum melted material. All three materials show change in the slope of the $\log$ stress versus $\log$ rupture time curve at approximately the same rupture time (600 to 900 hours at $\left.1300^{\circ} \mathrm{F}\right)$.

The double vacuum melted material (Lot 42402) tested at 1200 and at $1300^{\circ} \mathrm{F}$ shows an interesting comparison. The breaks in the rupture curve at 1200 and $1300^{\circ} \mathrm{F}$ occur at approximately the same rupture time; however, the stress levels are much higher for the 1200 data, and it appears that the increased stress just offsets the lower temperature. It would, therefore, follow from this line of thinking that the operating mechanism which causes the break in the rupture curves is both temperature and stress dependent. For the material and test condition described here, the difference in temperature between 1200 and $1300^{\circ} \mathrm{F}$ corresponds to a stress difference of about 19,000 to 33,000 psi.

Figure 3 shows a comparison of $1300^{\circ} \mathrm{F}$ test results from both fine and coarse-grained, plug drawn tubing with the test results from coarsegrained, planetary swaged material; all double vacuum melted Type 316 stainless steel is in the 20 percent cold worked condition.

There is only a slight difference attributable to grain size in the two plug drawn lots out to about 800 to 900 hours; at that point there is a break in each curve. Thereafter, the coarse-grained, plug drawn material has significantly better stress rupture strength. 


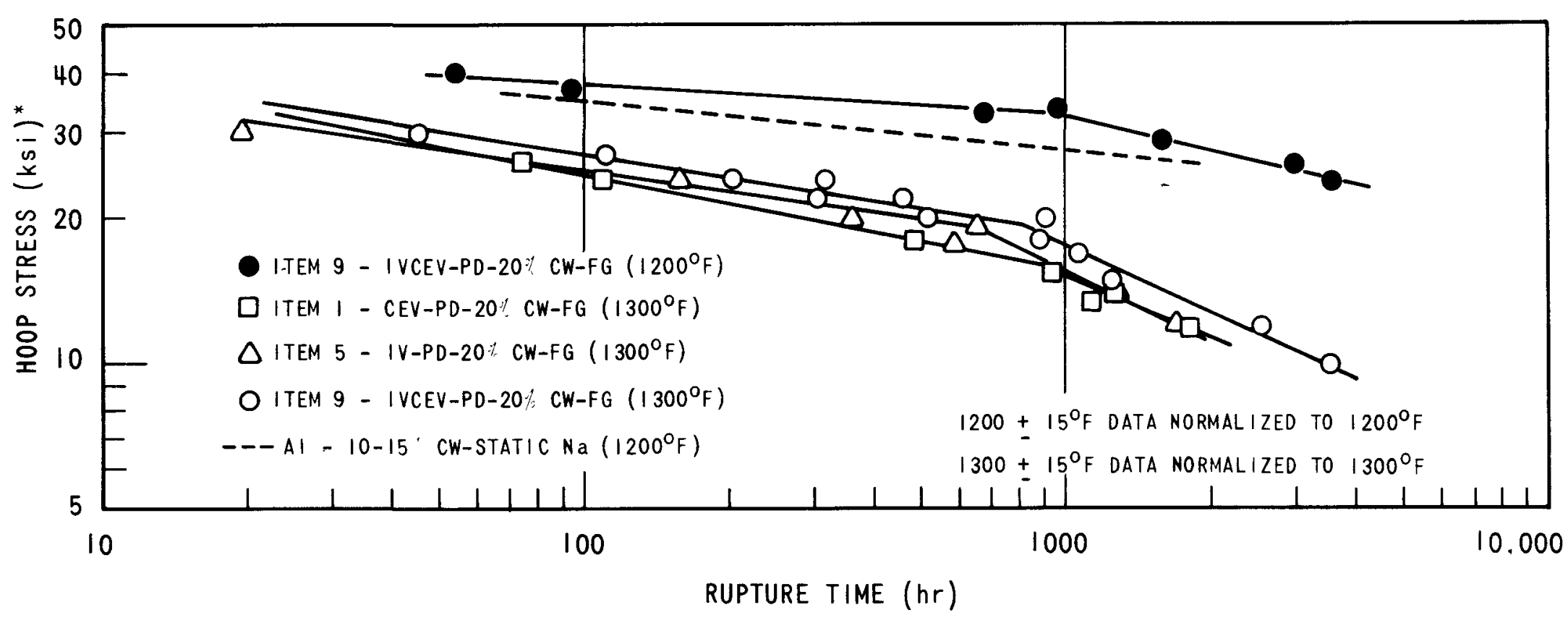

*STRESS BASED ON MID-WALL RADIUS

Figure 2. Biaxial Stress Rupture Results for Plug Drawn, Type 316 Stainless Steel Tubing Fabricated by Three Vacuum Melting Practices (Fine Grain, 20\% Cold-Worked) 
D
y
in

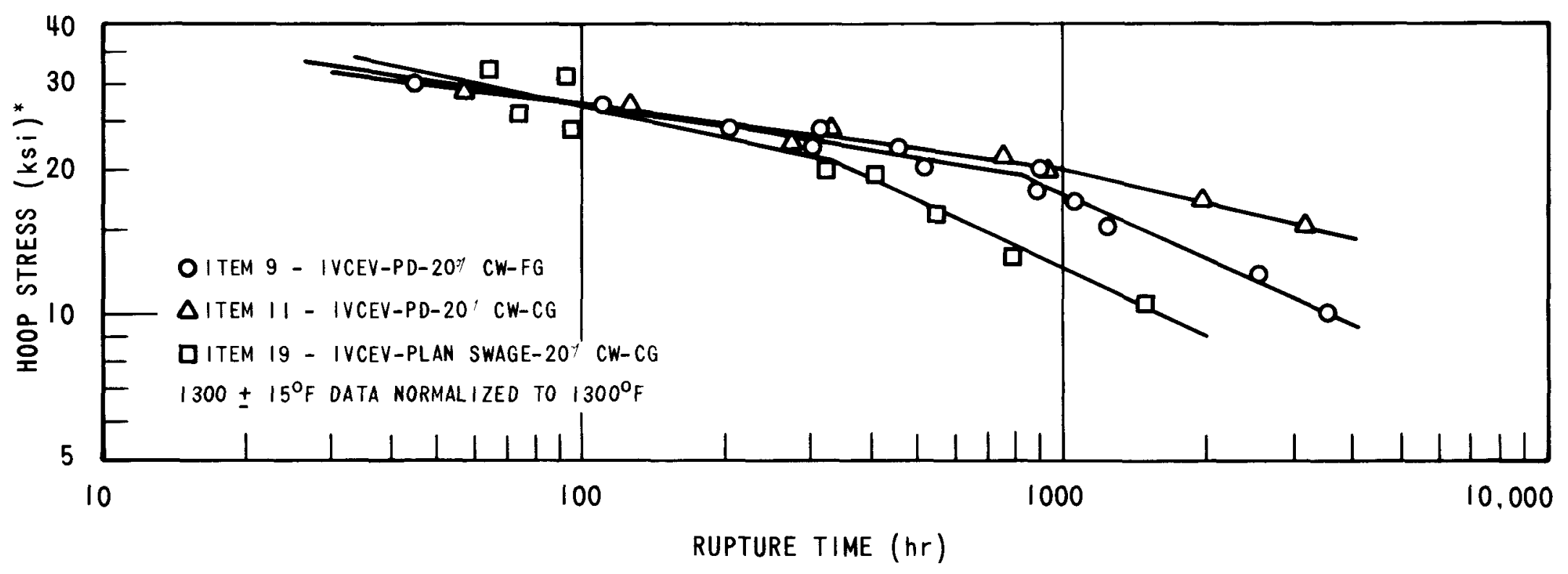

*STRESS BASED ON MID-WALL RADIUS

Figure 3. Biaxial Stress Rupture Results for Cold-Worked Type 316 Stainless Steel Tubing, Fabricated by Plug Drawing and by Planetary Swaging 
The coarse-grained, planetary swaged lot shows a similar break in the curve at about the same stress as the plug drawn lots, but it occurs at a much shorter time, about 300-400 hours. This difference is not attributable to grain size, based on comparison of the two lots tested having the same grain size.

Figure 4 shows a comparison for the annealed condition between fine-grained, plug drawn tubing and coarse-grained, planetary swaged tubing. Contrary to results from tubing in the cold worked condition, there is no significant difference between the plug drawn and the planetary swaged tubing in the annealed condition.

Figure 5 is a comparison of the annealed and the cold worked conditions for plug drawn material with fine grain size. Whereas the cold worked material starts out with much higher stress rupture strength than the annealed material, there is a break in its stress rupture line, occurring at about 800 to 900 hours and 19,000 to 20,000 psi, causing a change in slope and intersection with the line for the annealed material at about 2700 hours and 11,000 psi. Beyond the intersection, the annealed material has better stress rupture life and superior rupture ductility.

Figure 6 is a similar comparison of the annealed and cold worked conditions for planetary swaged tubing with coarse-grain size. Qualitatively the curve shapes are similar to the plug drawn materials in that the break in the curve occurs at about the same stress levels (21,000 to 22,000 psi), but the break occurs at much shorter time ( 300 to 400 hours), and the intersection occurs at about 700 hours and 14,000 psi.

Previous characterization results indicated that the cold worked, planetary swaged lot had a higher level of effective cold work than the plug drawn lots in spite of the fact that both types of material received the same nominal cold work, based on percent reduction in cross-sectional area after the last anneal. The cold worked, planetary swaged lot had higher hardness, faster precipitation kinetics, and a electron transmission microstructure characteristic of much higher cold work than the plug drawn lot. The plug drawn and the planetary swaged, annealed materials on the other hand were similar in hardness and transmission microstructure, and the only difference found in the material properties attributable to the difference in fabrication history was a slight difference in crystallographic texture.

Considering these pre-test characterization results, together with the lack of differences in the stress rupture curves for the annealed condition and the significant difference in the cold worked condition even at the same grain size, it appears that the differences observed in the stress rupture characteristics of cold worked, plug drawn and planetary swaged tubing are the result of the higher level of effective cold work in the planetary swaged material.

\subsubsection{Biaxial Stress Rupture Testing In Argon}

In preparation for the Defects Evaluation Task, three furnaces were converted to argon atmosphere, biaxial stress rupture facilities. The 


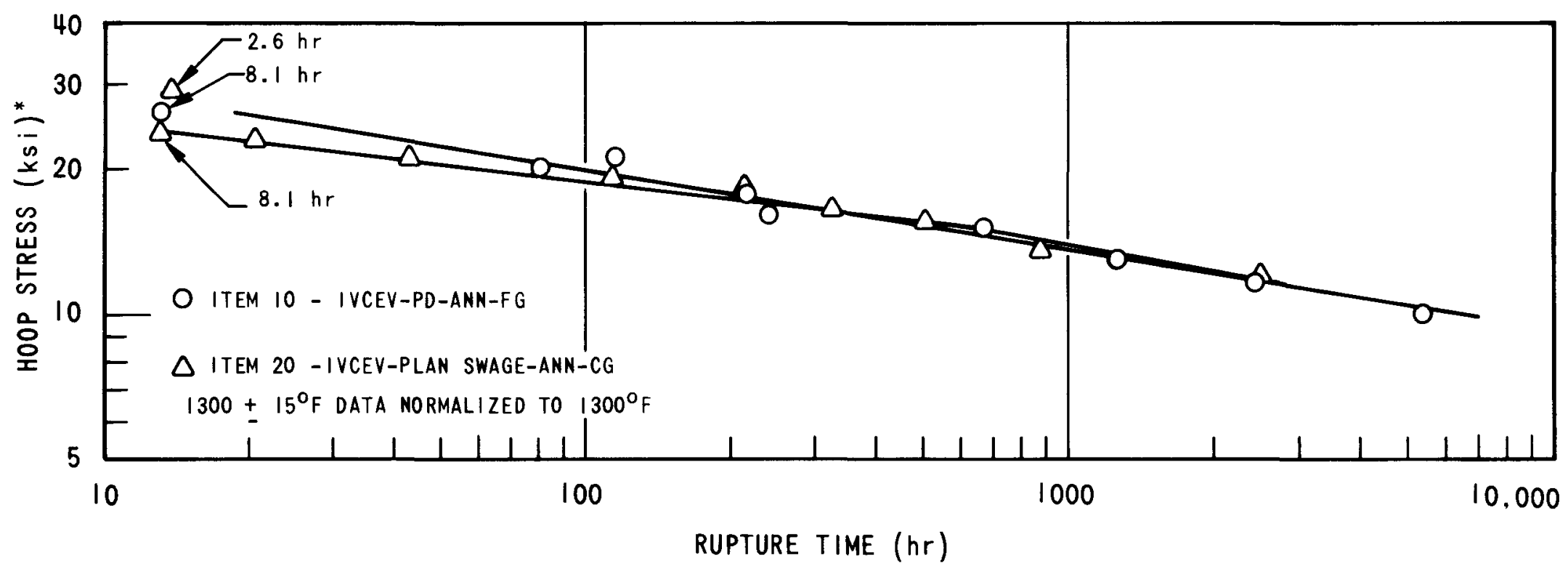

*STRESS BASED ON MID-WALL RADIUS

Figure 4. Biaxial Stress Rupture Results for Annealed Type 316 Stainless Steel, Fabricated by Plug Drawing and by Planetary Swaging 


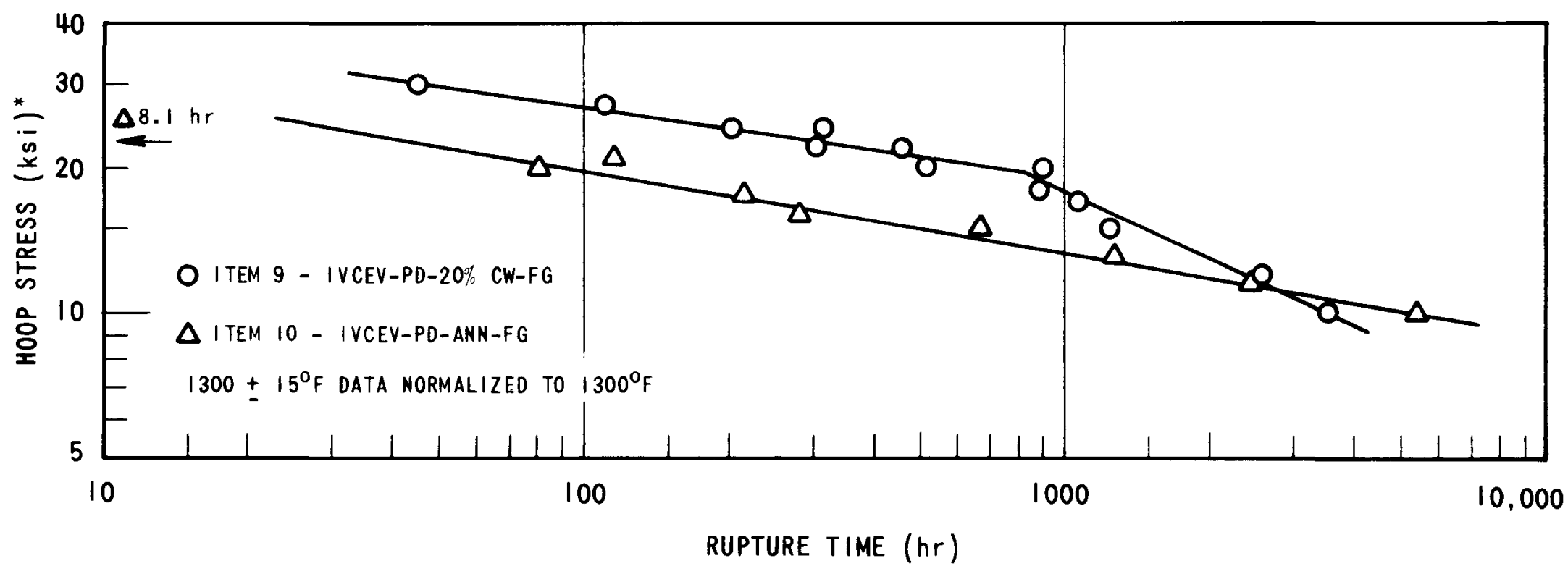

* STRESS BASED ON MID-WALL RADIUS

Figure 5. Biaxial Stress Rupture Results for 20 Percent Cold-Worked and Annealed Type 316 Stainless Steel Tubing 


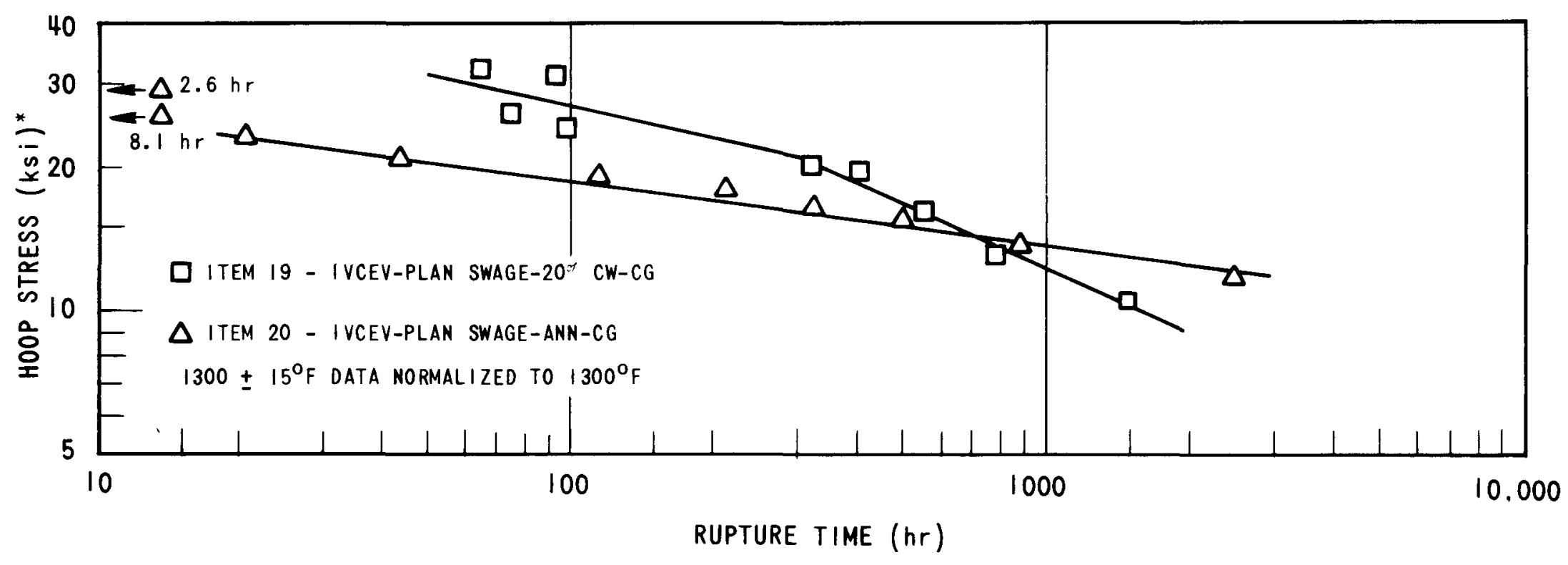

*STRESS BASED ON MID-WALL RADIUS

Figure 6. Biaxial Stress Rupture Results for Planetary Swaged, Type 316 Stainless Steel Tubing IGrain Size 6 - Annealed and 20 Percent Cold-Workedl 
results from the first five runs used to test the equipment are given in Table 3. These speciemens were made from the same lot of cold worked tubing, and tested under the same nominal conditions. One test was discontinued as a result of a leak in the pressurizing equipment. Two of the specimens contained intentional electro-discharge machined (EDM) defects. Although these broke with shorter stress rupture times than the control specimen, the ruptures did not occur at the EDM notches but at longitudinal handling scratches,

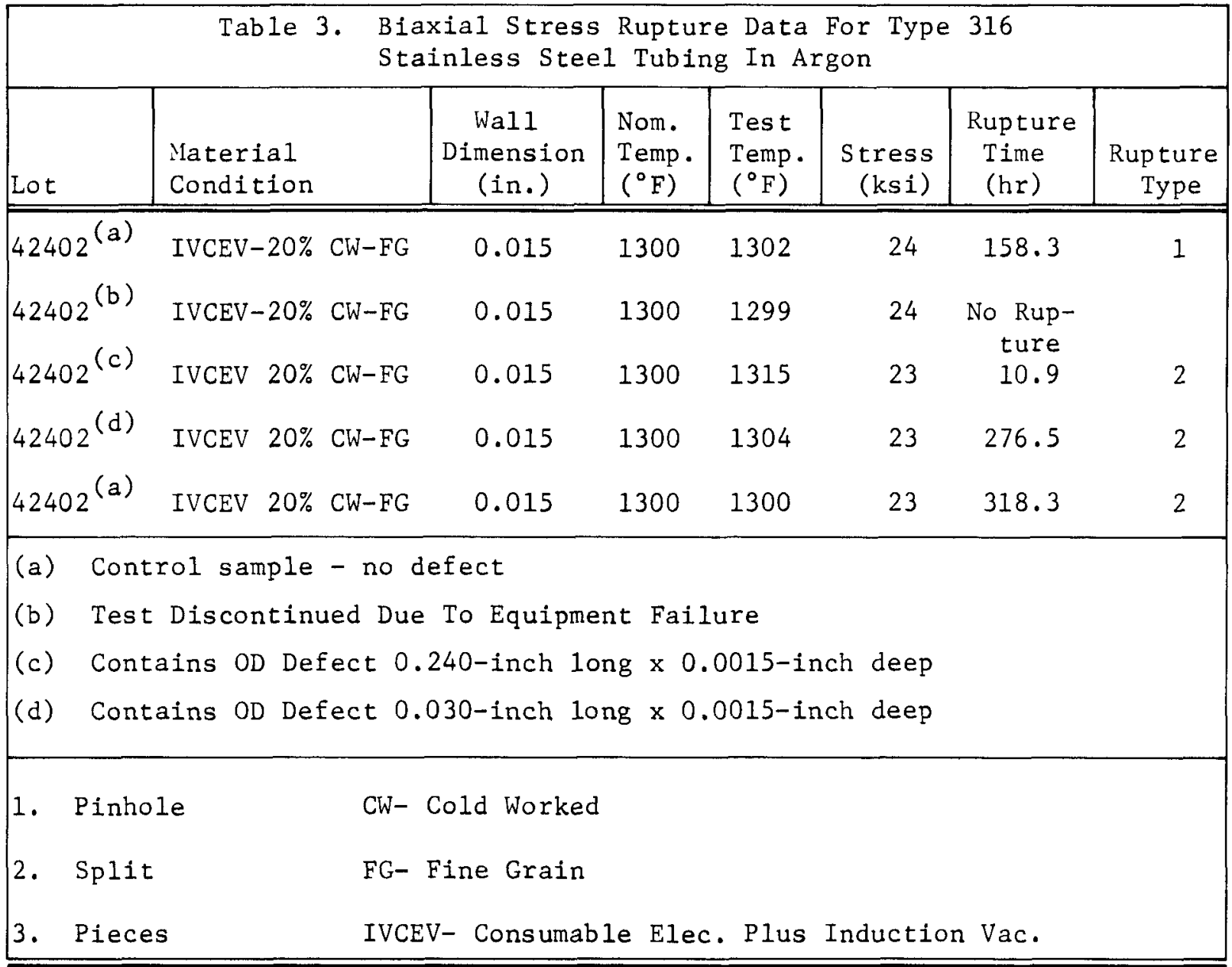

located near the plug end of each specimen. Interpretation is reserved for the present, however, on the relative effects of scratches and EDM notches. Diametral strain profile measurements along the lengths of these specimens indicated there was some difficulty with the specimen fabrication or in the heat zones of the furnace at the time of these runs. There appeared to be a systematic bias favoring rupture near the plug end of the specimen. Three additional specimens from the same fabrication lot have been inserted into the furnaces; three thermocuple has been attached to each specimen. A fourth specimen was inserted in one of the air atmosphere furnaces as a check on the specimen fabrication. 


\subsubsection{Uniaxial Creep}

The uniaxial creep unit utilizing a Gaertner miscroscope ${ }^{[2]}$ for measurement is now operational. Creep measurements are being made on lot number 42402, 20 percent cold worked, double vacuum melted Type 316 stainless steel tubing. The test conditions are $1200^{\circ} \mathrm{F}$ and 15,000 psi stress in vacuum; this specimen has accumulated 400 hours of test. A second unit, which is nearing completion, will be used to test the reference tubing at $1200^{\circ} \mathrm{F}$ and 12,000 psi.

\subsection{Post-Test Specimen Characterization - Biaxial Stress Rupture ilorphology Correlation}

Classification of post-test rupture morphology continued. The additional results from the Vacuum Melted Steels Task further support the observations reported previously.

1. The cold worked, planetary swaged material tends to rupture with a Type 1 fracture (Pinhole).

2. The annealed materials tend to fail with a high fraction of Type 2 or Type 3 rupture (Splits or multiple pieces).

3. The cold worked, plug drawn materials are intermediate (failure Types 1 and 2).

4. In general the tendency for Type 1 rupture is greater at lower stresses.

To better illustrate point number 4, Table 4 was constructed from all of the $1300^{\circ} \mathrm{F}$ stress rupture results from the Vacuum Melted Steels Task. In this table the various lots of materials are ranked according to increasing tendency to fail by pin hole rupture. Rupture morphology is classified according to the code indicated, and recorded according to the engineering hoop stress of the tests. The dividing line of the table separates the stress region of mixed type rupture from stress region of pin hole rupture only.

At stress levels below 13,000 psi only pin hole ruptures were observed for the twelve lots of Type 316 stainless steel tested, including three annealed lots. When the classification is limited to cold worked materials, the dividing stress is $18,000 \mathrm{psi}$ at $1300^{\circ} \mathrm{F}$. While there is no guarantee that these results are directly applicable to irradiated materials they do indicate directions for consideration in planning irradiation tests and evaluation results.

In addition to the four points listed previously, the table also illustrates that the tendency to form pin hole ruptures increases as the grain size is increased from ASTM 9 to ASTM 5.5/6 for the cold worked condition. 


\begin{tabular}{|c|c|c|c|c|c|c|c|c|c|c|c|c|c|c|c|c|c|c|c|c|c|c|c|c|c|}
\hline & & Table 4 & $\begin{array}{l}\text { tainle } \\
1300^{\circ} \mathrm{F}\end{array}$ & Nor & $\begin{array}{l}\text { Stee } \\
\text { mina }\end{array}$ & $\begin{array}{ll}21 & 5 \\
1 & 1\end{array}$ & $\begin{array}{l}\text { Biax } \\
\text { Temp }\end{array}$ & $\begin{array}{l}\text { ial } \\
\text { era }\end{array}$ & $\begin{array}{l}\text { Str } \\
\text { ture }\end{array}$ & $\begin{array}{l}\text { ress } \\
\text { e }(t\end{array}$ & $\begin{array}{l}\mathrm{Ru} \\
15\end{array}$ & $\begin{array}{l}{ }^{\circ} \mathrm{ptu} \\
\left.{ }^{\circ} \mathrm{F}\right)\end{array}$ & $\begin{array}{l}\text { Ire } \mathrm{F} \\
\text { Air }\end{array}$ & $\begin{array}{l}\text { Frac } \\
\text { r At }\end{array}$ & $\begin{array}{l}\text { ctur } \\
\text { tmos }\end{array}$ & $\begin{array}{l}\mathrm{Ce} C \mathrm{Cl} \\
\text { spher }\end{array}$ & $\begin{array}{l}\text { lass } \\
\text { re }\end{array}$ & sifi & cat & ion & & & & & \\
\hline & felting & Fabrication & & & & & & & & & & & Stres & is (1 & $10^{3}$ & psi) & & & & & & & & & \\
\hline Condition & Practice & Practice & $\begin{array}{l}\text { Grain } \\
\text { Size }\end{array}$ & 32 & 31 & 30 & 29 & 28 & 27 & 26 & 25 & 24 & 23 & 22 & 21 & 20 & 19 & 18 & 17 & 16 & 15 & 14 & 13 & 12 & 11 \\
\hline CW & IVCEV & PS & 6 & 1 & 2 & 1 & & 1 & & 1 & & 1 & & 1 & & 1 & & & & 1 & & & 1 & & 1 \\
\hline $\mathrm{CW}$ & CEV & PD & $5.5 / 6$ & & & 2 & & 1 & & 1 & & 1 & & 1 & & & & & & & & 1 & & & \\
\hline $\begin{array}{l}\mathrm{CW} \\
\mathrm{GH} T \\
\mathrm{GH} \mathrm{T}\end{array}$ & IVCEV & PS & 6 & & & & 2 & & & 1 & & & & & 1 & & & 1 & & & & & & & \\
\hline $\mathrm{CW}$ & IV & PD & $5.5 / 6$ & & & 1 & & 1 & & 2 & & 1 & & 1 & & 1 & & & & & & & & & \\
\hline $\begin{array}{l}\mathrm{CW} \\
\mathrm{GHT} \\
\end{array}$ & IVCEV & $\mathrm{PD}$ & 9 & & & 3 & & 3 & & 3 & & 3 & & 1 & & 1 & & & & & & & & & \\
\hline $\mathrm{CW}$ & IVCEV & $P D$ & $5.5 / 6$ & & & 3 & 2 & 2 & 2 & 1 & & 2,1 & & 2,1 & 2 & 1 & 1 & & 1 & & 1 & & & & \\
\hline CW & IVCEV & PD & 9 & & & 2 & & 1 & 1 & 1 & & 3 & & 2 & & 1 & & 1 & 1 & & 1 & & & 1 & \\
\hline $\mathrm{CW}$ & IV & $\mathrm{PD}$ & 9 & & & 1 & & 2 & & 2 & & 2 & & 2 & & 1 & 1 & 1 & & & & 1 & & & \\
\hline $\mathrm{CW}$ & CEV & $\mathrm{PD}$ & $9 / 9.5$ & & & 1 & & 2 & & 1 & & 1 & & 1 & & 2 & & I & & 1 & & 1 & & & \\
\hline A.V. & CEV & PD & 8 & & & & & & & & & 2 & & 1 & & 2 & & 2 & & 1 & & 1 & & & \\
\hline A.VN & IVCEV & PS & 6 & & & & 3 & & & 2 & & & 3 & & 2 & & 2 & 2 & & 2 & 1 & 1 & & 1 & \\
\hline AN N & IVCEV & $P D$ & 8 & & & & & & & & 3 & 2 & & 2 & 2 & 3,2 & & 2 & & 1 & 2 & 3 & 1 & 1 & \\
\hline $\begin{array}{ll}\text { 1. } & \text { Pinhol } \\
\text { 2. } & \text { uplit } \\
\text { 3. } & \text { Pieces }\end{array}$ & e Rupture & $\begin{array}{r}\mathrm{PL} \\
\mathrm{PS} \\
\mathrm{Ch} \\
\mathrm{ANN}\end{array}$ & $\begin{array}{l}\text { - Plug } \\
\text { - Plane } \\
\text { - 20\% } \\
\text { - Anne: }\end{array}$ & $\begin{array}{l}\text { Draw } \\
\text { etary } \\
\text { Cold } \\
\text { aled }\end{array}$ & $\begin{array}{l}\text { wn } \\
\text { y Swe } \\
\text { Work }\end{array}$ & $\begin{array}{l}\text { aged } \\
\text { ked }\end{array}$ & & & & & & & & $\begin{array}{l}\mathrm{CEV}- \\
\mathrm{TV}- \\
\mathrm{CLV}- \\
\mathrm{CHT}-\end{array}$ & $\begin{array}{l}-\mathrm{Co} \\
-\mathrm{In} \\
-\mathrm{Co} \\
-\mathrm{Ga}\end{array}$ & $\begin{array}{l}\text { nsuma } \\
\text { iducti } \\
\text { nsuma } \\
\text { rofal }\end{array}$ & $\begin{array}{l}\text { able } \\
\text { ion } \\
\text { able } \\
\text { lo } H\end{array}$ & $\begin{array}{l}\text { Eled } \\
\text { Vzcu } \\
\text { Eled } \\
\text { eat }\end{array}$ & $\begin{array}{l}\text { c. } \\
\text { um } \\
\text { c. P } \\
\text { Treat }\end{array}$ & lus & Indu & ction & & cuum & \\
\hline
\end{tabular}


Preliminary results from measurements in progress of $\Delta D / D$ at the pin hole ruptures of these specimens indicate that the lower the ductility of the material the greater the tendency to form pin hole ruptures. For example, typical $\triangle D / D$ ductilities for the cold worked, planetary swaged lot at the top of the table are 6.9 percent and those for the annealed, plug drawn lot or the bottom of the table are 35 to 38 percent. Those for the cold worked, fine-grained, double vacuum melted lot (42402) are intermediate (10 to 12 percent). Additional $\Delta \mathrm{D} / \mathrm{D}$ measurements are planned to better establish this ductility correlation.

\subsection{Post-Stress Rupture Specimen Characterization - Vacuum Mlelted Steels Task}

Diametral strain profile measurements have been made for seven additional specimens from the Vacuum Melted Steels Program. Wall thinning measurements, $\Delta t / t_{0}$, have also been made from two transverse sections for each of five of these specimens. The procedures were the same as reported previously.[9] Figures 7 and 8 show the strain profile measurements and the locations from which the transverse sections were taken. Figures 9 and 10 show the wall thinning results. The data points for each section in these plots are arbitrarily connected by straight lines except for the rupture areas which are left open. Pinhole ruptures in Figures 7 and 8 are indicated by arrows. It should also be noted that there is a difference in the $\Delta t / t_{0}$ scale factor between the annealed and the cold worked specimen plots.

These $\Delta t / t_{0}$ measurements generally confirmed the observation reported previously:

1. All of the specimen sections containing the rupture areas and most of the other sections showed non-uniform wall thickness reduction during test, indicating some type of circumferential heterogenity in the pre-test tubing.

2. In all five specimens, the maximum $\Delta t / t_{0}$ was observed in the section containing the rupture and, except for one section, the maximum $\Delta t / t_{0}$ was located circumferentially near the rupture. The exception was the plug drawn, annealed specimen which had a low stress and long rupture time. In this specimen there were two thin areas in the same transverse plane.

3. As would be expected, the annealed materials had the highest $\Delta t / t_{0}$ values since they had the highest average ductilities as measured by $\Delta \mathrm{D} / \mathrm{D}$. However, these later $\Delta t / t_{0}$ measurements did not indicate greater wall thickness variation in annealed specimens than in cold worked specimens as was observed previously.

4. In four out of five specimens the relative positions of the $\Delta t / t_{0}$ maxima in the non-ruptured sections were not aligned with the maxima of the ruptured specimens, indicating that the source of the pre-test non-uniformity was not longitudinally aligned. In the annealed, planetary swaged specimen there was no siginificant maximum in the non-ruptured section. 

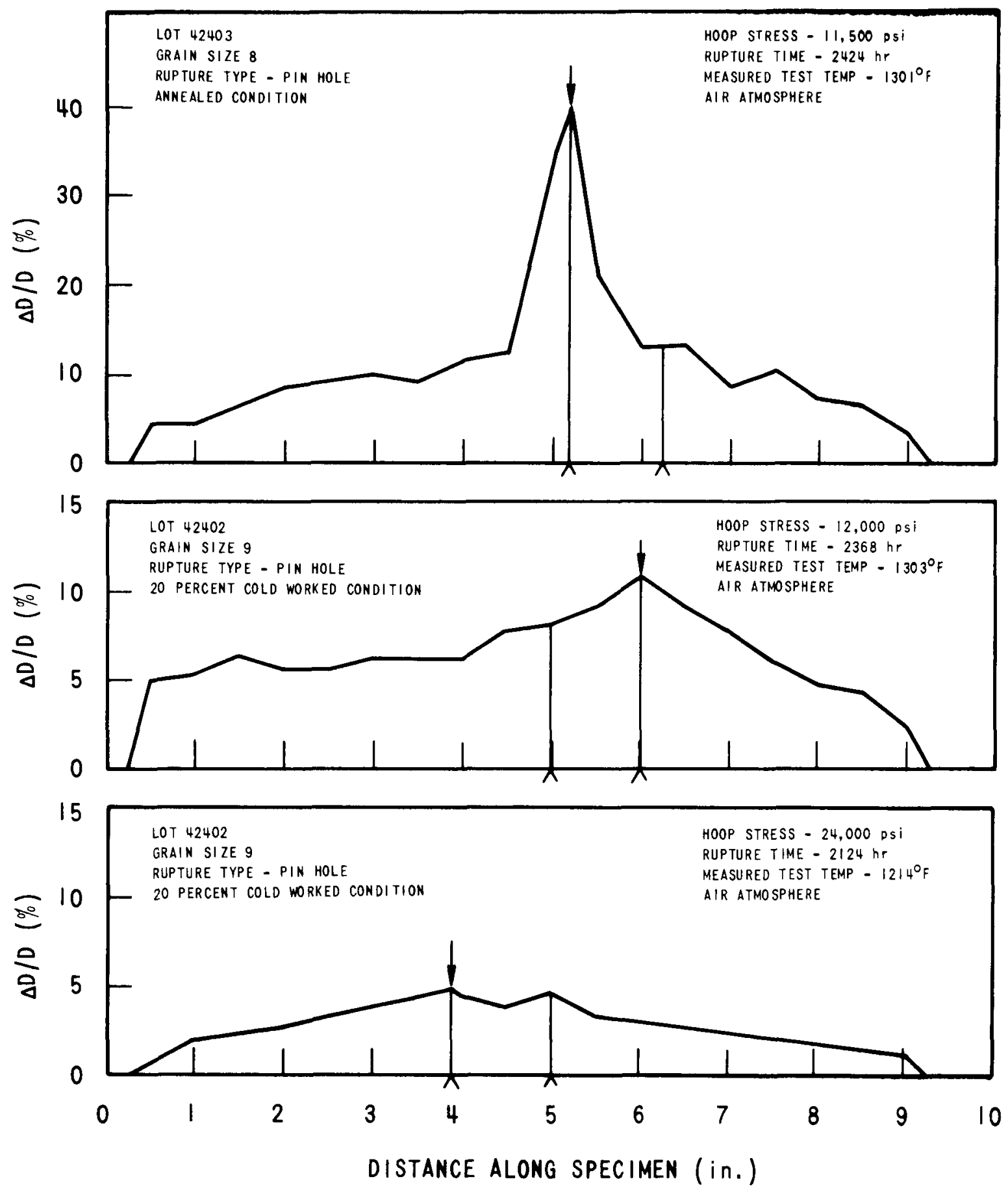

$\lambda$ LOCATION OF TRANSVERSE SECTION USED

FOR WALL THINNING MEASUREMENTS

I LOCATION OF PIN HOLE RUPTURE

Figure 7. Plug Drawn Tubing - Strain Profiles for Post-Test, Stress Rupture Specimens

4027-7 

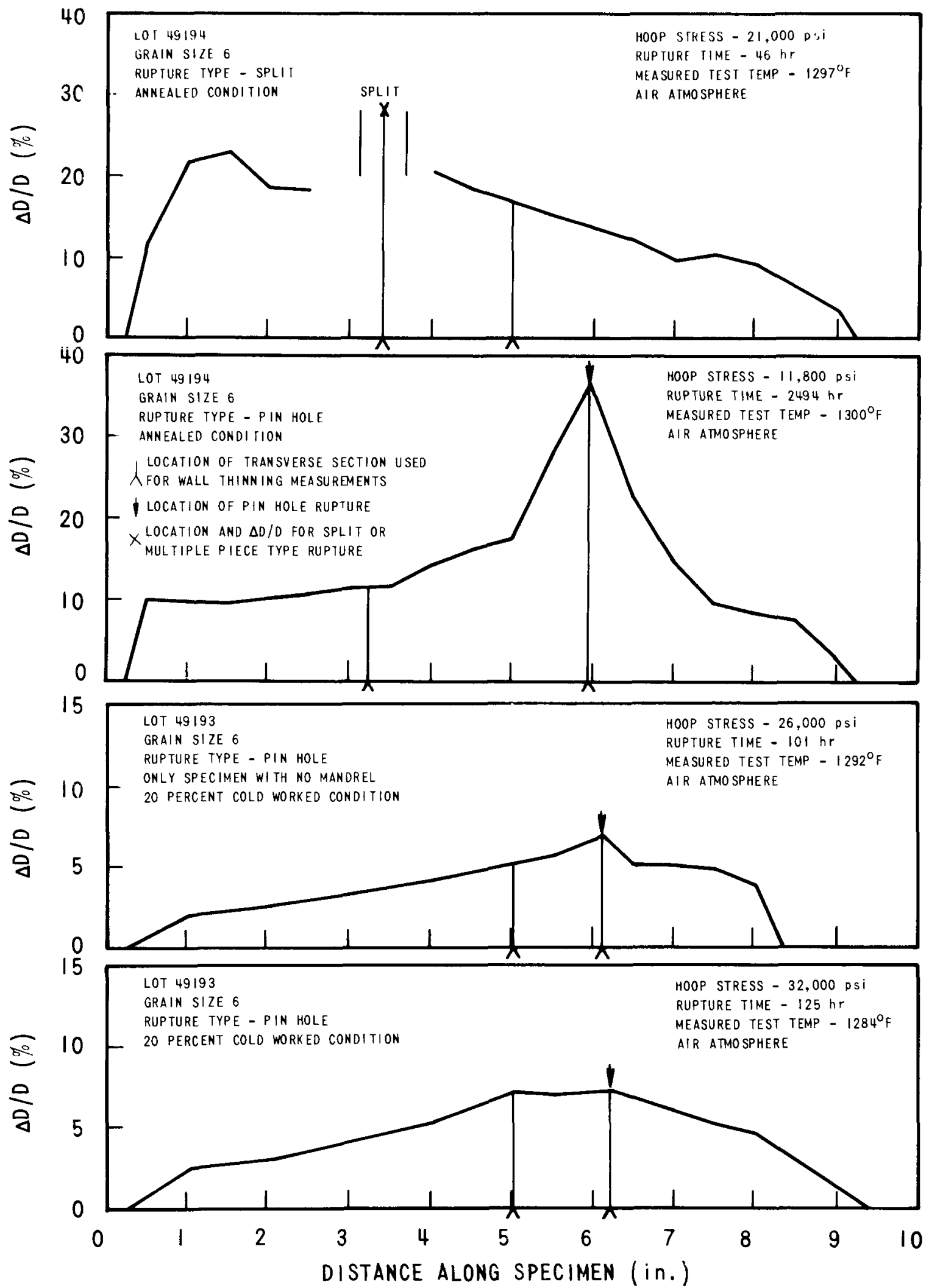

Figure 8. Planetary Swaged Tubing - Strain Profiles for Post-Test, Stress Rupture Specimens

$4027-8$ 

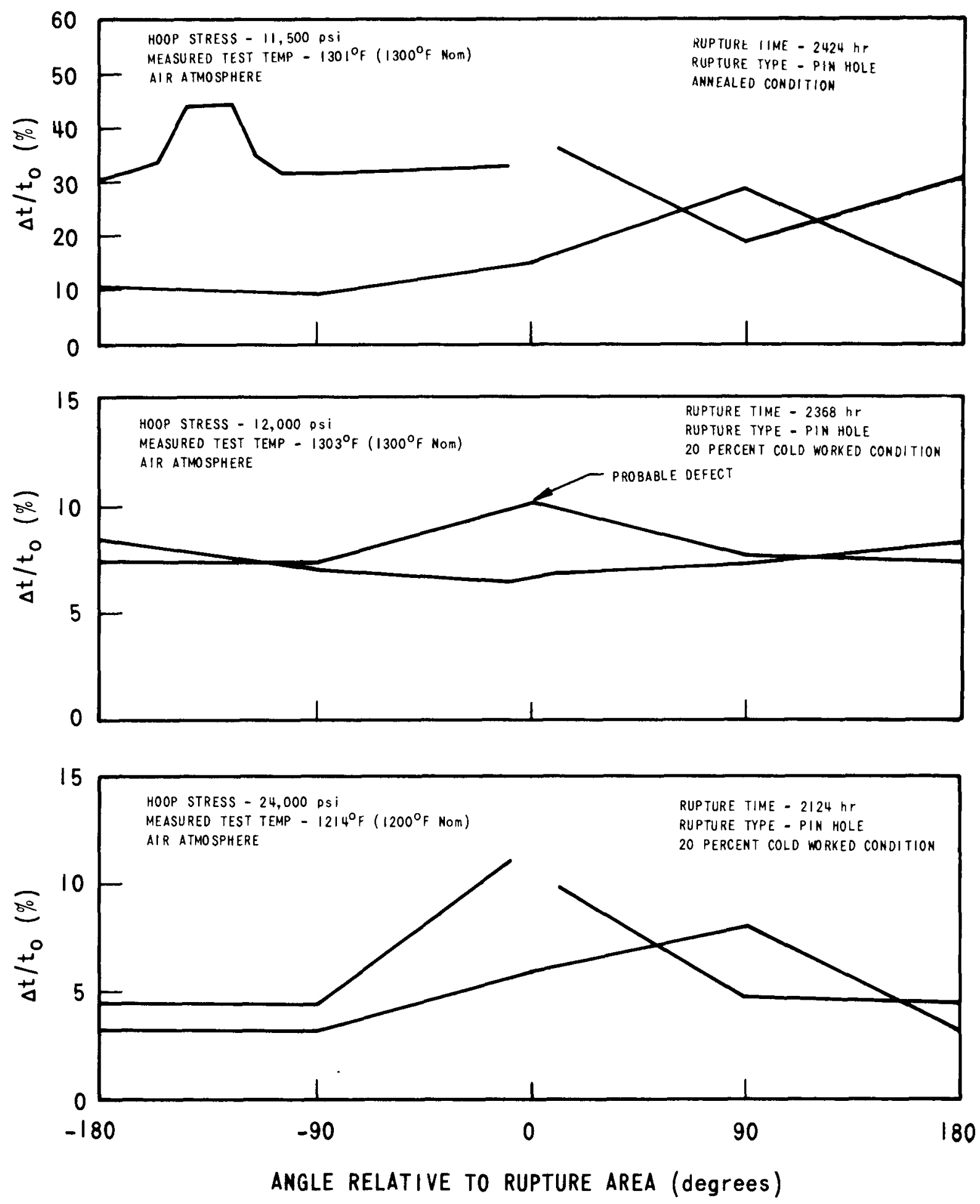

Figure 9. Wall Thinning Measurements, $\Delta t / t_{0}$, Versus Angle Relative to Rupture Area for Plug Drawn, Fine Grained Type 316 Stainless Steel Specimens

$4027-9$ 

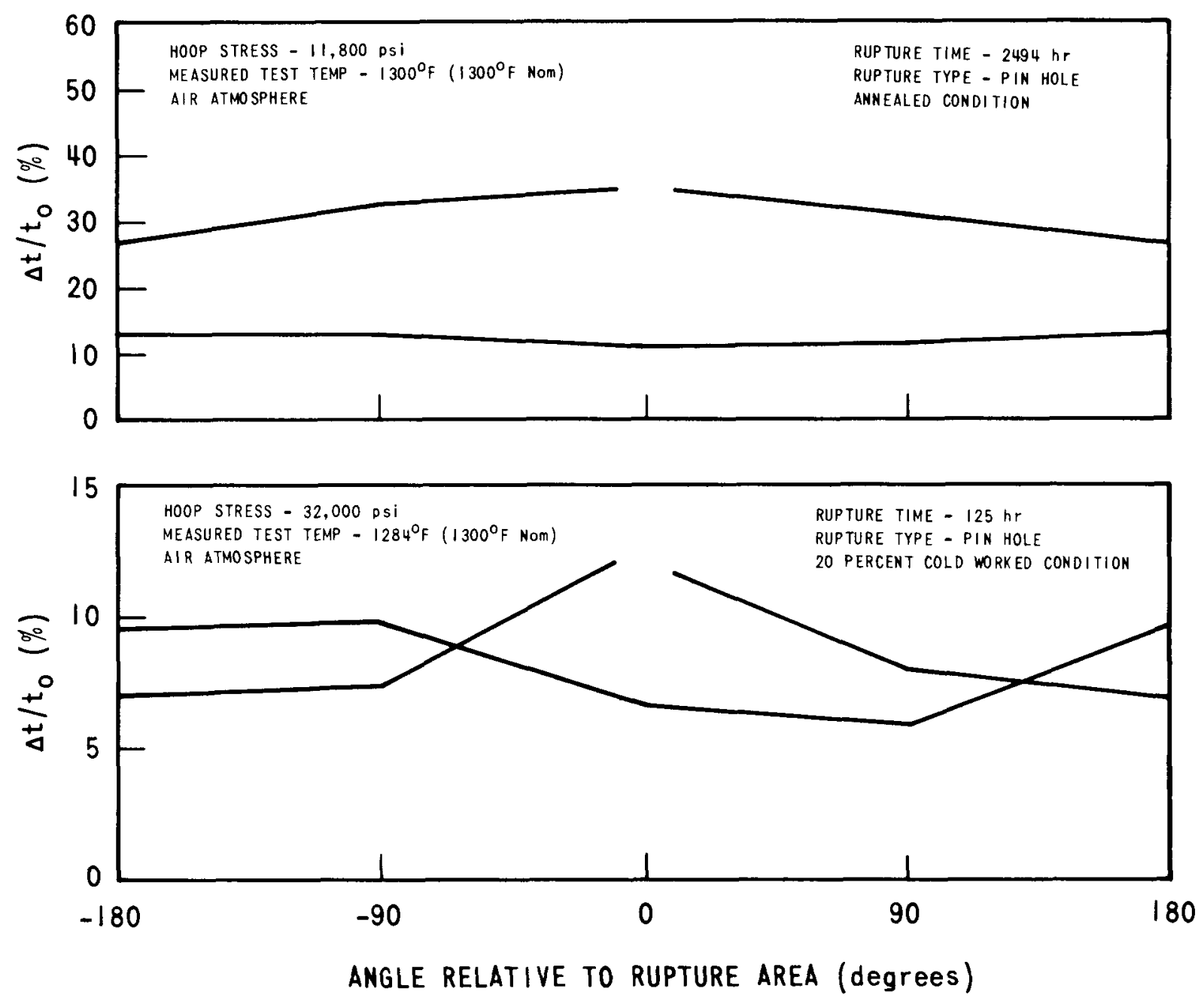

Figure 10. Wall Thinning Measurements, $\Delta t / t_{o}$, Versus Angle Relative to Rupture Area for Planetary Swaged, Coarse Grained Type 316

$4027-10$ Stainless Steel Specimens 
5. In these later specimens, the greatest wall thickness variations was not always observed in the long term tests. Combining these results with previous measurements, [9] it appears that the time period of stress rupture tests is not an important variable with respect to severity of wall thinning variation during test.

No observations were made from these five specimens which are contradictory to the interpretation and the discussion reported in Reference 9 other than the minor differences included above.

These five specimens complete the post-test, wall thickness measurements planned for the Vacuum Melted Steels Task. The observations and the procedures, together with pretest NDT characterization will be applied to the Defects Evaluation Task which will receive the main emphasis for the remainder of FY-1971.

In Reference 9 it was anticipated that preliminary evaluation of defected specimens would be completed in time for this report. Because of a series of delays in setting up new equipment and procedures conforming with RDT standards, specimens which would yield significant results were not obtained in time for evaluation and reporting here.

\subsection{Post-Test : letallographic Characterization}

\subsubsection{Vacuum ilelted Steels Task}

The five post-test specimens characterized by $\Delta t / t_{0}$ measurements were further evaluated by metallographic examination. The structures observed are illustrated in Figures 11, 12, and 13. Emphasis was placed on the significant combinations of test conditions and materials not covered previously.

\subsubsection{Annealed, Plug Drawn Specimen}

The annealed, plug drawn specimen which had been tested at $1301^{\circ} \mathrm{F}$ and relatively low stress ( 11,500 psi) ruptured with a pin hole after 2424 hours. The diametral strain at the rupture area, corrected for the pinhole width, was 40.0 percent as measured by $\Delta D / D$. The rupture appeared to initiate on the $O D$. A transverse section near the longitudinal position of the rupture showed two thin areas in the wall relative to other locations in the same transverse plane as illustrated in Figure 11. This is the only specimen of all those examined in this program, which showed two thin areas.

In both of these thin areas, large cavities and some grain separation were observed. The microstructure contained two size classes of precipitates. The smaller had a general distribution with no strong preference for grain boundaries; this precipitate class had the appearance of a carbide. The larger size class tended to be located on grain boundaries and had the appearance of an intermetallic; frequently, the cavities were associated with these larger precipitates. Conclusive identification of the precipates by electron probe and diffraction analysis is planned. 
OD

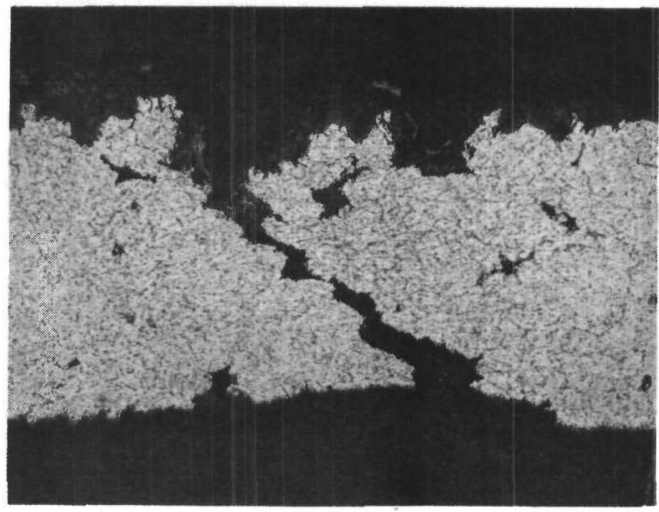

ID

a. PIN HOLE RUPTURE AREA

OD

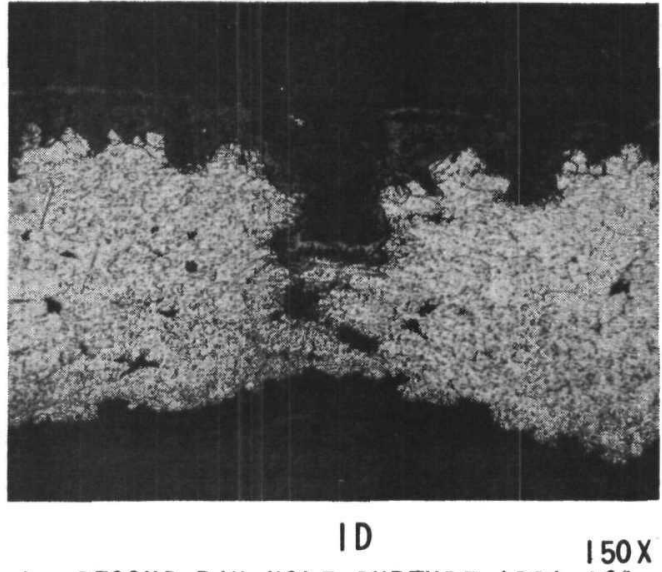

b. SECOND PIN HOLE RUPTURE AREA I 20

DEGREES ANGULAR AWAY IN SAME TRANSVERSE SECTION OD

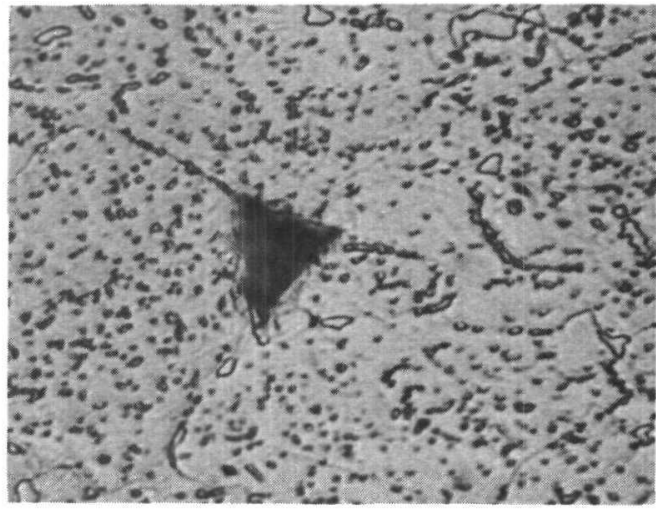

ID

c. AREA NEAR RUPTURE

$1000 x$

Figure 11. Post-Test Stress Rupture Specimen - Plug Drawn, Annealed, Lot 42403, Grain Size 8 - Rupture Time 2424 hr, Hoop Stress 11, 500 psi, $1301^{\circ} \mathrm{F}$ in $\mathrm{Air}$ 
OD

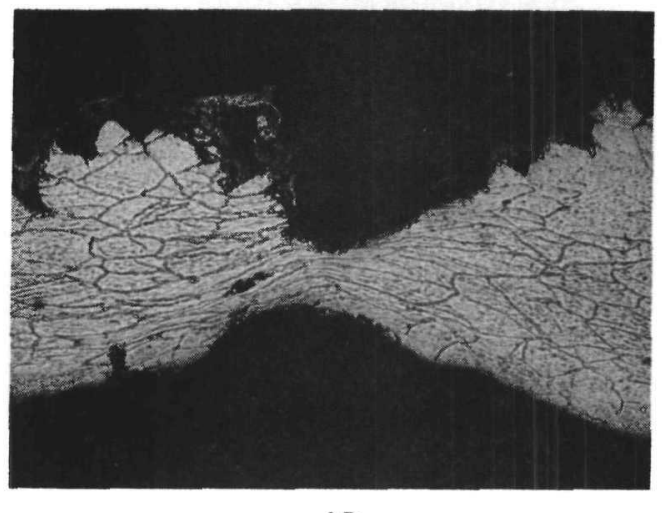

ID

a. PIN HOLE RUPTURE AREA

$150 x$

OD

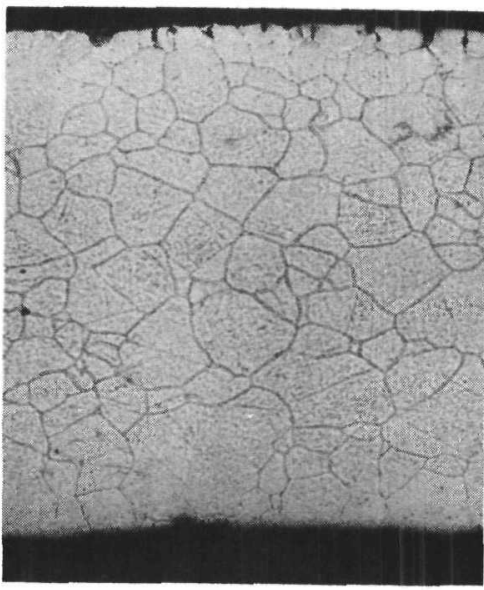

ID I50X

c. 180 DEgREES ANGULAR

FROM RUPTURE AREA

OD

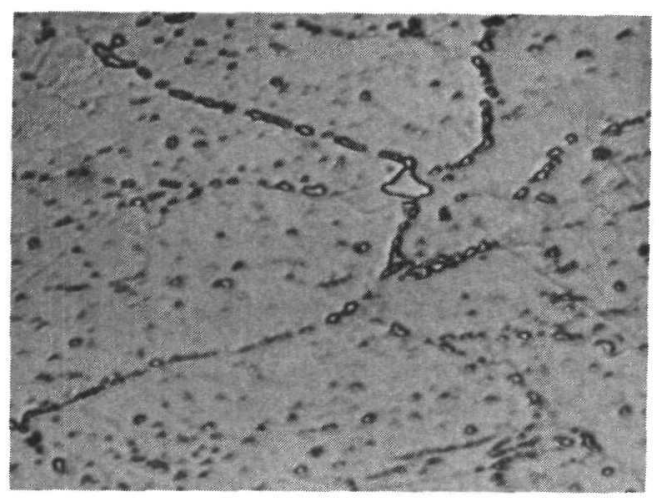

ID

b. PIN HOLE RUPTURE AREA

$1000 x$

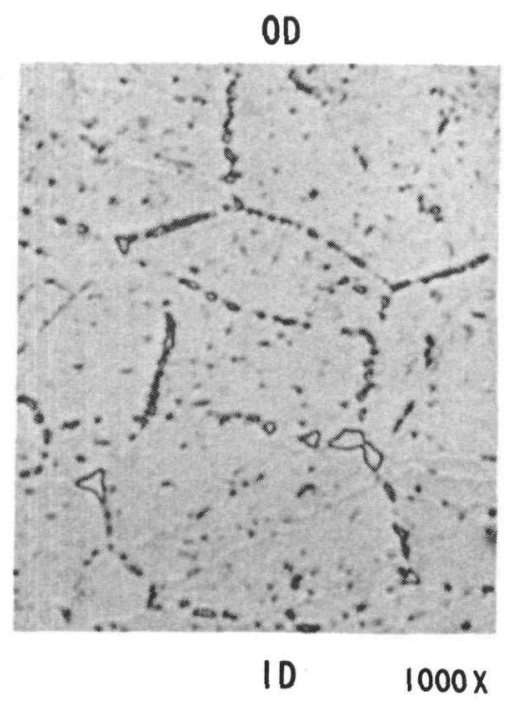
d. 180 DEGREES ANGULAR
FROM RUPTURE AREA

Figure 12. Post-Test Stress Rupture Specimen - Planetary Swaged, Annealed, Lot 49194, Grain Size 6 - Rupture Time 2494 hr, Hoop Stress

$4027-12$ $11,800 \mathrm{psi}, 1300^{\circ} \mathrm{F}$ in Air 
OD

OD

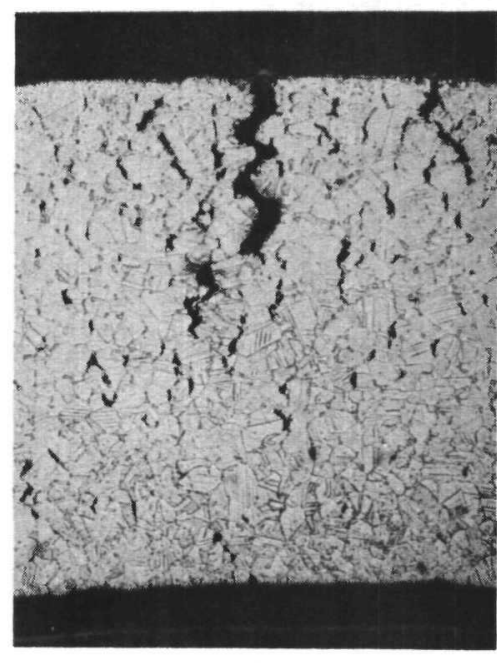

ID

a. PIN HOLE RUPTURE AREA

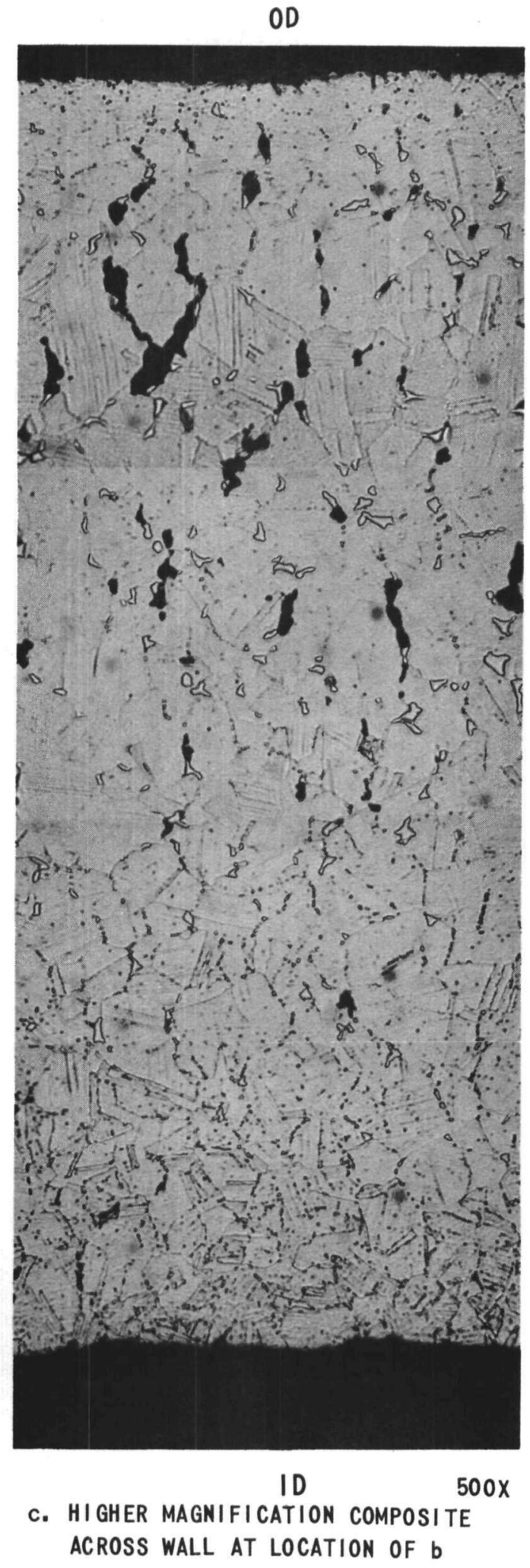

Figure 13. Post-Test Stress Rupture Specimen - P1ug Drawn, 20 Percent Cold Worked, Lot 42402, Grain Size 9 - Rupture Time $2368 \mathrm{hr}$, Hoop

$4027-13$

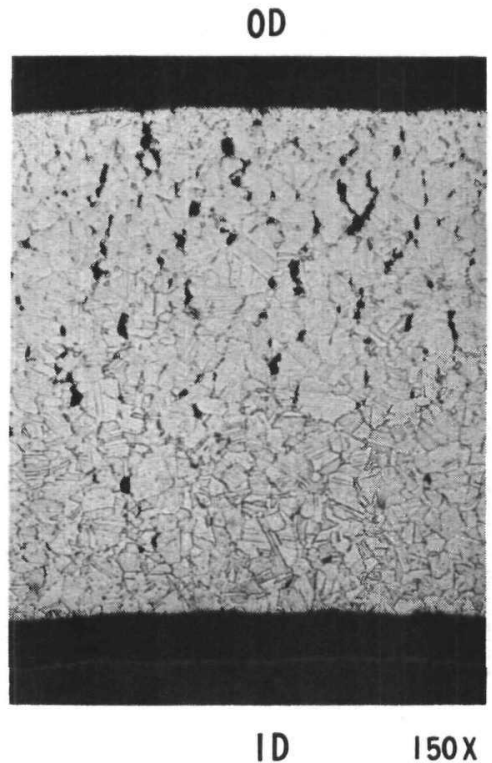

b. 20 DEGREES ANGULAR

FROM RUPTURE AREA Stress $12,000 \mathrm{psi}, 1303^{\circ} \mathrm{F}$ in $\mathrm{Air}$ 


\subsubsection{Annealed, Planetary Swaged Specimen}

The annealed, planetary swaged specimen examined had almost identical test conditions to the annealed, plug drawn specimen $(11,800$ psi compared to $11,500 \mathrm{psi})$. It ruptured in 2429 hours, also with a pinhole initiating on the $0 D$. The diametral strain at the rupture area was 36.0 percent. The microstructure (Figure 12) of this specimen was different from the annealed, plug drawn specimen in that it had fewer cavities, fewer precipitates of both size classes, and a greater tendency for the precipitates to be located on the grain boundaries. Both annealed specimens showed grain elongation near the rupture.

Both annealed specimens also exhibited severe oxidation on the OD; the oxide thickness was correlated with the local wall thickness reduction. This correlation existed in comparisons of various circumferential locations in the transverse plane containing the rupture, and in other planes of the specimens where there was less than average wall strain.

The enhanced oxidation is probably the result of repeated breakdown of the protective oxide layer as the OD circumference increases and the wall thickness decreases. This local enhanced oxidation rate could, in turn, also tend to increase the local strain rate by causing significant wall thickness reduction. Taking these two processes together and neglecting notch effects, the enhanced oxidation and the wall-thickness reduction should shorten stress rupture life under these conditions. It is interesting to note, however, that these two annealed materials had the greatest stress rupture life, for the low stress levels, of any of the materials tested (see Figures 5 and 6).

As part of the Defects Evaluation Task, specimens of the same and similar materials will be tested in an argon atmosphere. Results from two preliminary tests in an argon atmosphere (out to about 250 hours at $1300^{\circ} \mathrm{F}$ ) indicate that, at least for cold worked tubing, the argon test results fall on the air test curve for the same material.

\subsubsection{Cold Worked, Plug Drawn Specimen - High Temperature}

The cold worked, plug drawn specimen (lot 42402), tested at $1303^{\circ} \mathrm{F}$ and 12,000 psi hoop stress, ruptured at 2368 hours with a diametral strain of 8.1 percent $\triangle D / D$ at the pin hole rupture; the rupture time of this specimen was beyond the break in the stress rupture curve. The microstructure near the pin hole rupture and 20 degrees away from the rupture, in the same transverse plane is illustrated by Figure 13. The rupture initiated at the $O D$, and the microstructure showed numerous radially oriented grain boundary cavities with a higher concentration near the OD than near the ID of the tube. The cavities in the cold worked specimen were distributed around the circumference and near the rupture, and were present in non-rupture sections from the same specimen; whereas the large voids observed in the annealed specimen tested under similar conditions were associated with the rupture area only. 
The two size classes of precipitates were again observed, but compared to the annealed specimen, the cold worked specimen had fewer smal], intragranular precipitates, and a higher concentration of the larger intermetallic type precipitates located in grain boundaries. The concentration of these precipitates was higher at the mid-wall and near the OD than near the II). Many of the cavities were associated with these precipitates.

The specimen also showed marked variation in grain size across the wall. Based on previous results ${ }^{[9]}$ from post-test, cold worked, planetary swaged specimens, recrystallization and growth was expected in this plug drawn specimen. The structure indicates that there has been a significant grain growth in the outer two thirds of the wall, but it cannot be stated categorically that recrystallization has also occurred. This type of grain size variation was not observed in post-test specimens from this tubing lot which were located before the break on the stress rupture curve.

\subsubsection{Cold Worked, Plug Drawn Specimen - Low Temperature}

A similar specimen from lot 42402 , tested at lower temperature $\left(1214^{\circ} \mathrm{F}\right)$ and higher stress $(24,000$ psi) ruptured at 2129 hours, with diametral strain of 4.8 percent. This specimen also failed by pinhole rupture initiating on the OD.

The microstructure of the lower temperature specimen (Figure 14), relative to the higher temperature specimen, shows fewer grain boundary cavities, fewer large intermetallic type precipitates, a higher concentration of fine intragranular precipitates, and only a slight increase in grain size across the wall.

\subsubsection{Cold Worked, Planetary Swaged Specimen}

The fifth specimen examined was a cold worked, planetary swaged specimen, tested at $1284^{\circ} \mathrm{F}$ and $32,000 \mathrm{psi}$, and failed at 125 hours with a diametral strain of 7.2 percent $\triangle D / D$. This specimen had a pin hole rupture but unlike the longer-term, lower stress specimens from the same lot, [9] the rupture initiated at the OD and did not show the recrystallized grain structure near the $O D$ which was observed in the specimens located after the break on the stress rupture curve. These observations are consistant with the interpretations made previously[9] for this 1 ot of material.

The specimen contained only a few large cavities located primarily near the rupture and near the OD. It also contained fewer of the larger size class of precipitates than the longer-term specimens from the same lot of material, and those precipitates present did not have significantly higher concentration near the OD than near the ID.

\subsubsection{Future Plans}

Several items remain to complete the metallography planned for the Vacuum Melted Steels Task. They are: 
$O D$

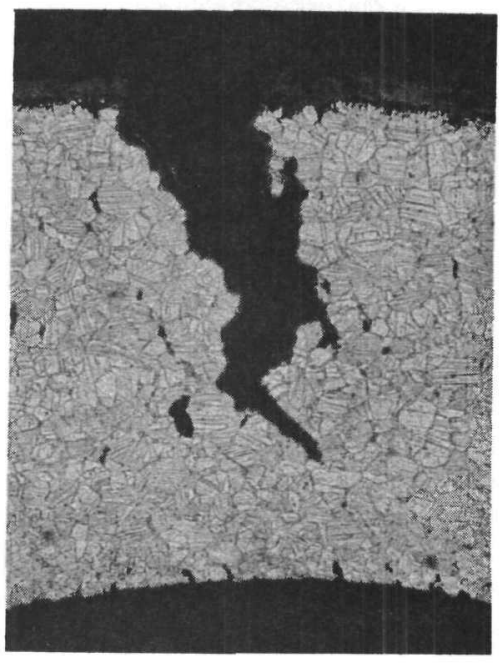

ID

a. PIN HOLE RUPTURE AREA

OD

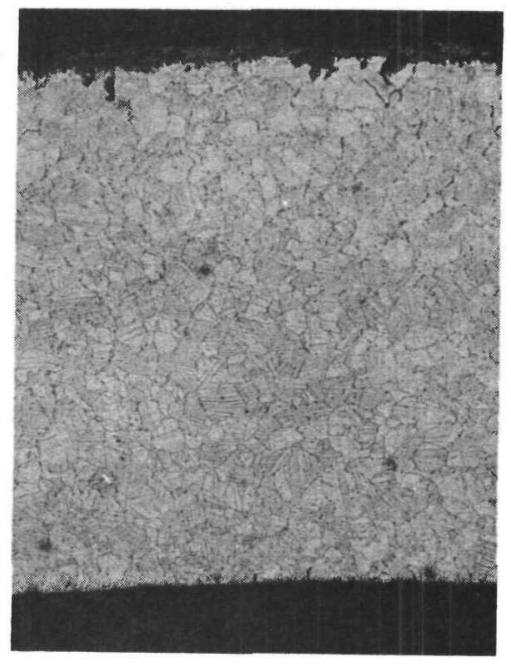

ID I50X

c. 20 DEGREES ANGULAR FROM RUPTURE AREA
OD

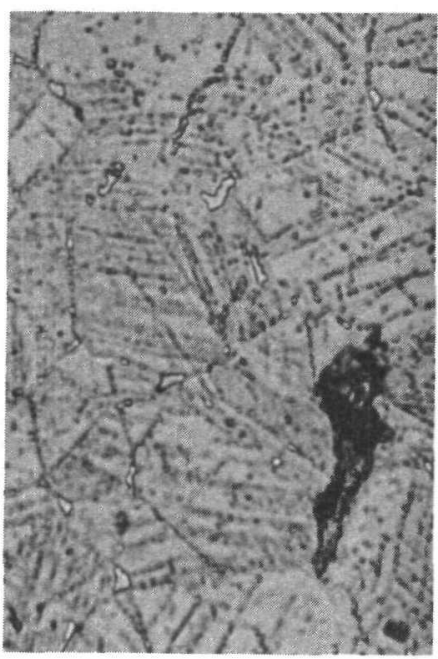

ID

$1000 x$

b. PIN HOLE RUPTURE AREA

$O D$

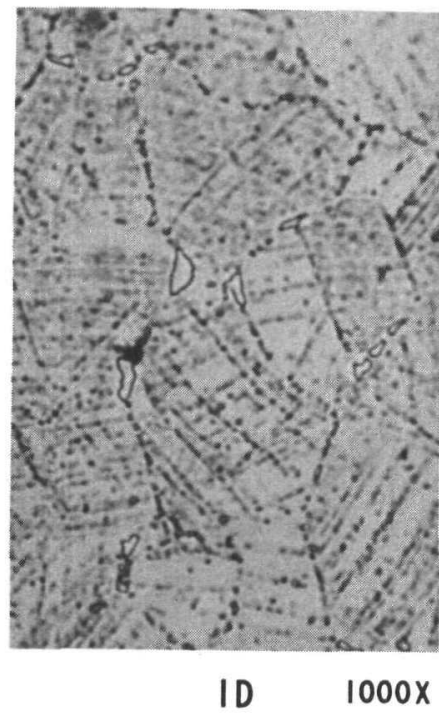

d. 20 DEGREES ANGULAR

FROM RUPTURE AREA

Figure 14. Post-Test Stress Rupture Specimen - Plug Drawn, 20 Percent Cold Worked, Lot 42402, Grain Size 9 - Rupture Time 2124 hr, Hoop $4027-14$ Stress $24,000 \mathrm{psi}, 1214^{\circ} \mathrm{F}$ in $\mathrm{Air}$ 
1. Identification of precipitates by electron probe analysis and by $\mathrm{X}$-ray diffraction.

2. Examination of selected specimens after cathodic etching.

3. Combining all of the metallographic observations, obtained step wise, into a general evaluation of the post-test rupture specimens from this program.

\subsubsection{Effects of Cold Work on Rupture Life}

Hardness results are currently being collected from several sources, including ARD, WADCO, Atomics Internationa1, and Argonne National Labs. These data will be used, along with plots of 1000-hour rupture life versus percent cold work, to determine levels of cold work introduced by various fabrication processes, and to relate DPH hardness values with cold work. Results are inconclusive as of now since hardness data from several sources are limited.

\subsubsection{Reports and Papers}

A topical report, covering the Vacuum Melted Steels Program, is being written. Completion is expected during the January to March 1971 report period. A paper entitled "Development of Type 316 Stainless Steel Tubing for LMFBR Fuel Element Cladding," by T. R. Padden, W. E. Ray, H. J. Snyder, and $\mathrm{K}$. C. Thomas, was presented at the winter Meeting of the ANS in Washington, D. C.

\subsection{Literature Survey}

In preparation for the Defects Evaluation Task a literature survey was made on the influences of defects on mechanical properties of fuel cladding. The results of the survey are summarized in the following paragraphs.

\subsubsection{Artificial Defect Study At General Electric}

High strain rate burst tests[11] were performed on 0.250 -inch oD by 0.015 -inch wall Type 316 stainless steel tubing at 1100 and $1300^{\circ} \mathrm{F}$. Tests of specific interest to ARD were those performed on seamless, drawn tubing made from Superior heat number 20303. These test specimens were 3-1/2 inches long, internally pressurized, and tested in air at $1300^{\circ} \mathrm{F}$.

Six samples of seamless, annealed tubing were artificially defected by lathe machining. Defects ranged from $0.8 \mathrm{mils}$ to $2.9 \mathrm{mils}$ in depth; all defects were $125 \mathrm{mils}$ long and were oriented longitudinally along the tube. In addition, three control samples were tested. All six defected samples falled at the defect but showed a reduction in hoop stress of only 0 to 9 percent. Samples containing defects less than 10 percent of wall falled with severe transverse tearing. Samples containing defects greater 
than 10 percent of wall failed with small splits, showing little deformation. Diametral strain measurements were not available.

\subsubsection{Natural Defect Study At General Electric}

Thirteen samples were prepared for testing at $1300^{\circ} \mathrm{F}$, three of which were control samples. Ten samples contained natural defects from 0.7 to $1.5 \mathrm{mils}$ in depth. Of these, only two samples failed at the defect. In all cases, reduction in hoop stress was less than 7 percent. Reduction in diametral strain ranged from 0 to 50 percent, with higher reductions observed in samples containing deeper defects.

\subsubsection{Other Studies At General Electric}

Additional tests were performed at $1100^{\circ} \mathrm{F}$ and an artificially defected, welded-and-drawn tubing. The results were similar, showing little reduction in hoop strength due to defects. However, location of failure and reduction of ductility are dependent on defect orientation.

G. E. has concluded from these tests that the 10 percent reject level (defect 10 percent of wall thickness) for Type 316 stainless steel cladding is completely adequate and probably conservative. However, this evidence is being substantiated with long-term stress rupture tests on similarly defected tubing.

\subsubsection{Studies At WADCO}

WADCO is using eddy current and ultrasonic test equipment to characterize tubing from various vendors and to implement a defect evaluation program for FFTF fuel cladding.[12,13] A statistical program was set-up to aid in evaluating the ultrasonic test equipment, and several lots of Type 316 stainless steel tubing have been successfully characterized.[14] In addition, hybrid eddy current testing technique is being developed, which will allow better resolution and sensitivity to tubing defects. [15]

WADCO is characterizing tubing from various vendors to establish defect levels. Biaxial stress rupture testing is being performed on 20 percent cold worked tubing, lot $\mathrm{N}$, which has been artificially defected by EDM machining. Initial results[16] had indicated that an axial flaw 3.3 percent of wall thickness on the ID surface had reduced stress rupture life by 25 percent at $1200^{\circ} \mathrm{F}$ and times greater than 400 hours. Identical OD surface defects appeared to have no effects on rupture life.

Later work ${ }^{[12]}$ has shown that biaxial stress rupture specimens at 1200 and $1400^{\circ} \mathrm{F}$, with defects 3.3 percent of wall thickness have all failed away from the defect for rupture times less than 1000 hours. Tests at $1400^{\circ} \mathrm{F}$ on defects 10 percent of wall thickness have also failed away from the defect. It was concluded that under these conditions, 20 percent cold worked Type 316 stainless steel cladding is not notch sensitive. 
Additional work is continuing to determine the effects of notch depth and location.

\subsubsection{Studies At ORNL}

Oak Ridge is developing eddy current methods for detecting flaws in stainless steel tubing so that the signals from flaws may be more readily distinguished from surface irregularities and other perturbing factors. A method is also being developed to measure amounts of cold work in stainless tubing by changes in magnetic permeability. $[17,18,19,20]$

Oak Ridge has performed room temperature burst tests on samples of 20 percent cold worked, Type 316 stainless steel tubing (ASTM grain size 5-6) which was fabricated to FFTF specifications by mandrel drawing and final plug drawing. The tubing was ultrasonically tested and regions containing natural defects were cut into tube burst specimens. Control samples with no detectable defects were also tested. The tubing also contained some eccentricity but was within specification. Out of nine samples tested, all failed at defects. Only one of the nine samples failed at a defect located in the thicker side of the wall; the other samples failed where the defect was located in the thinner side of the wall. No loss in strength was observed when the defect was located in the thick wall. However, a significant loss in burst strength and ductility was observed when the defect was located in the thin wall. [21]

Oak Ridge has hypothesized that the allowable eccentricity can obscure the effect of a defect on tube burst properties.[17]

Oak Ridge is also preparing a program to study the effects of artificial defects in stress rupture testing at $1200^{\circ} \mathrm{F}$. The samples are being prepared from 20 percent cold worked, Type 316 stainless steel tubing, having an ultrafine grain size (ASTM 14). The tubes are 0.250-inch OD by 0.016 -inch wall thickness. Twenty-one samples are to be tested containing artificial defects machined by EDM. The defects are $30 \mathrm{mils}$ long by $2.3 \mathrm{mils}$ wide and have a depth of 10,35, and 65 percent of wall thickness.[18] An additional 21 samples will be tested under similar conditions, except that the defect length will be $125 \mathrm{mils}$. Sections of annealed tubing are also being EDM machined for defect evaluation. [19]

Oak Ridge has been studying the effects of various fabrication procedures on the physical and mechanical properties of Type 316 stainless steel cladding. The effects of different mandrel drawing and annealing schedules on the structure and properties of finished tubing have been studied. The tubing is being tested nondestructively to FFTF specifications for flaws and eccentricity so that the defect frequency and effects may be related to fabrication history and mechanical properties. Planetary swaged tubing is also being fabricated to various schedules to study the effects of swaging. A combined process of mandrel drawing and planetary swaging has produced a tubing 10 percent higher in strength but lower in ductility than mandrel drawn tubing. In addition, an ultra fine grain size (ASTM 14) tubing has been developed, characterized by NDT methods, and tested in biaxial stress rupture. This tubing has proven to be lower in rupture life than conventionally produced tubing at $1200^{\circ} \mathrm{F}$ although slightly higher rupture ductilities were observed. $[17,19,20,21]$ 


\subsubsection{Studies At Argonne National Laboratory}

Early work at Argonne ${ }^{[22]}$ had indicated that artificially defected Type 304 stainless steel fuel cladding failed in stress rupture at defect sites even if the defects were only five percent of the wall thickness. The test samples were defected by EDM machining and were tested at $1200^{\circ} \mathrm{F}$. Both OD and ID defects were machined parallel to the tube axis and five percent of wall thickness.

Later tests were conducted on annealed Type 304 stainless fuel cladding which had passed NDT inspection requirements to eliminate defected material. The tubing was artificially defected with five percent defects located at 0,45 , and 90 degrees to the longitudinal axis, and tested in creep rupture $\left(1200^{\circ} \mathrm{F}\right.$ vacuum). Results indicated that five percent wall thickness defects can lower rupture ductility under biaxial load, and that such defects have a very high probability for a failure site. It was also found that ID defects, and those with a longitudinal orientation, were more probable as failure sites than other types of defects. [23] Long-term, creep rupture tests have been continuing on Type 304 stainless cladding with artificial defects located at 0,45 , and 90 degrees to longitudinal axis. Results of ruptures samples have shown that the defects oriented at 45 and 90 degrees to the axis have little or no effect on the rupture life.[24,25,26]

Argonne is developing pulsed eddy current techniques and is using the eddy current method to determine defects in thin-walled Type 304 stainless steel tubing, used in their defect evaluation program.[24] An investigation of several methods for determining amounts of cold work in Type 316 stainless steel is also in progress. Their investigations have shown a good correlation between magnetic retentivity and percent cold work. [27] 


\section{LIST OF REFERENCES}

1. F. Garofalo, F. Von Gemmingen, and W. F. Domis, "The Creep Behavior of an Austenitic Stainless Steel as Effected by Carbides Precipitated on Dislocations," Trans. Amer. Soc. Metals 54, pp. 430-444 (1961).

2. J. B. Conway and P. N. Flagella, "Physical and Mechanical Properties of Reactor Materials. Final Progress Report," GEMP-727, December 1969.

3. USAEC-PNL Drawing SK 3-15229, "Standard for Non-Destructive Testing of FFTF Fuel Cladding."

4. Specification ARD-AMMA-001-2, "Seamless Annealed Stainless Steel Tubing for Fuel Element Irradiation Studies," Modified to include cold worked tubing, May 1967.

5. "Stainless Steel Cladding Development. Quarterly Progress Report for Period Ending September 30, 1969," WARD-4135-2.

6. "Stainless Steel Cladding Development. Quarterly Progress Report for the Period Ending December 31, 1969," WARD-4135-5, February 1970.

7. "Stainless Steel Cladding Development. Quarterly Progress Report for Period Ending March 31, 1970," WARD-4135-9, Apri1 1970.

8. "Stainless Steel Cladding Development. Quarterly Progress Report for Period Ending June 30, 1970," WARD-4135-12, August 1970.

9. "Stainless Steel Cladding Development Quarterly Progress Report for the Period Ending September 30, 1970," WARD-4135-14, December 1970.

10. W. T. Lee, "Biaxial Stress-Rupture Properties of Austenitic Stainless Steels in Static Sodium," AI-AEC-12694, June 1968.

11. T. Lauritzen, A. Montes, and A. Conti, "Influence of Surface Defects on Short-Term Mechanical Properties of Austenitic Stainless Steel Tubing," GEAP-13550, December 1969.

12. "Fast Flux Test Facility Monthly Technical Progress Summary Report, October 1970," WHAN-IR-50, November 1970. (WADCO Corporation, Richland, Washington, OFFICIAL USE ONLY Report)

13. J. Ryden, Jr., "Nondestructive Testing of Small Diameter, Stainless Steel Fuel Clad Tubing," BNWL-SA-2275, 1969.

14. J. Ryden, Jr. and E. F. Perrizo, "The Nondestructive Examination of $G$ and H Lots FFTF Fuel Cladding," BNWL-1359, May 1970. 
15. J. Ryden, Jr., "An Eddy Current Tube Testing Technique Using a Hybrid Coil Configuration with Sequential Sampling," BNWL-1355, May 1970.

16. "Fast Flux Test Facility Monthly Technical Progress Summary Report, August 1970," WHAN-IR-27, September 1970. (WADCO Corporation, Richland, Washington, OFFICIAL USE ONLY Report)

17. "Fuel and Materials Development Program Quarterly Progress Report for Period Ending December 31, 1969," ORNL-4520, May 1970.

18. "Fuel and Materials Development Program Quarterly Progress Report for the Period Ending March 31, 1970," ORNL-4560, August 1970.

19. "Fuel and Materials Development Program Quarterly Progress Report for the Period Ending June 30, 1970," ORNL-4600, November 1970.

20. "Fuel and Materials Development Program Quarterly Progress Report for Period Ending September 30, 1969," ORNL-4480, February 1970.

21. "Fuels and Materials Development Program. Quarterly Progress Report for Period Ending June 30, 1969," ORNL-4440, October 1969.

22. "Reactor Development Program. Progress Report, October 1967," ANL-7391, November 1967.

23. F. L. Yaggee and I-Chih Wang, "Effect of Defects on the Rupture Ductility of Type-304 Stainless-Steel Tubes Under Biaxial Load," Trans. Am. Nuc1. Soc. 12, No. 2 (1969).

24. "Reactor Development Program Progress Report, February 1970," ANL-7669, March 1970.

25. "Reactor Development Program Progress Report, March 1970," ANL-7679, April 1970.

26. "Reactor Development Program Progress Report, April-May 1970," ANL-7688, July 1970.

27. "Reactor Development Program Progress Report, June 1970," ANL-7705, July 1970. 


\section{DISTRIBUTION LIST}

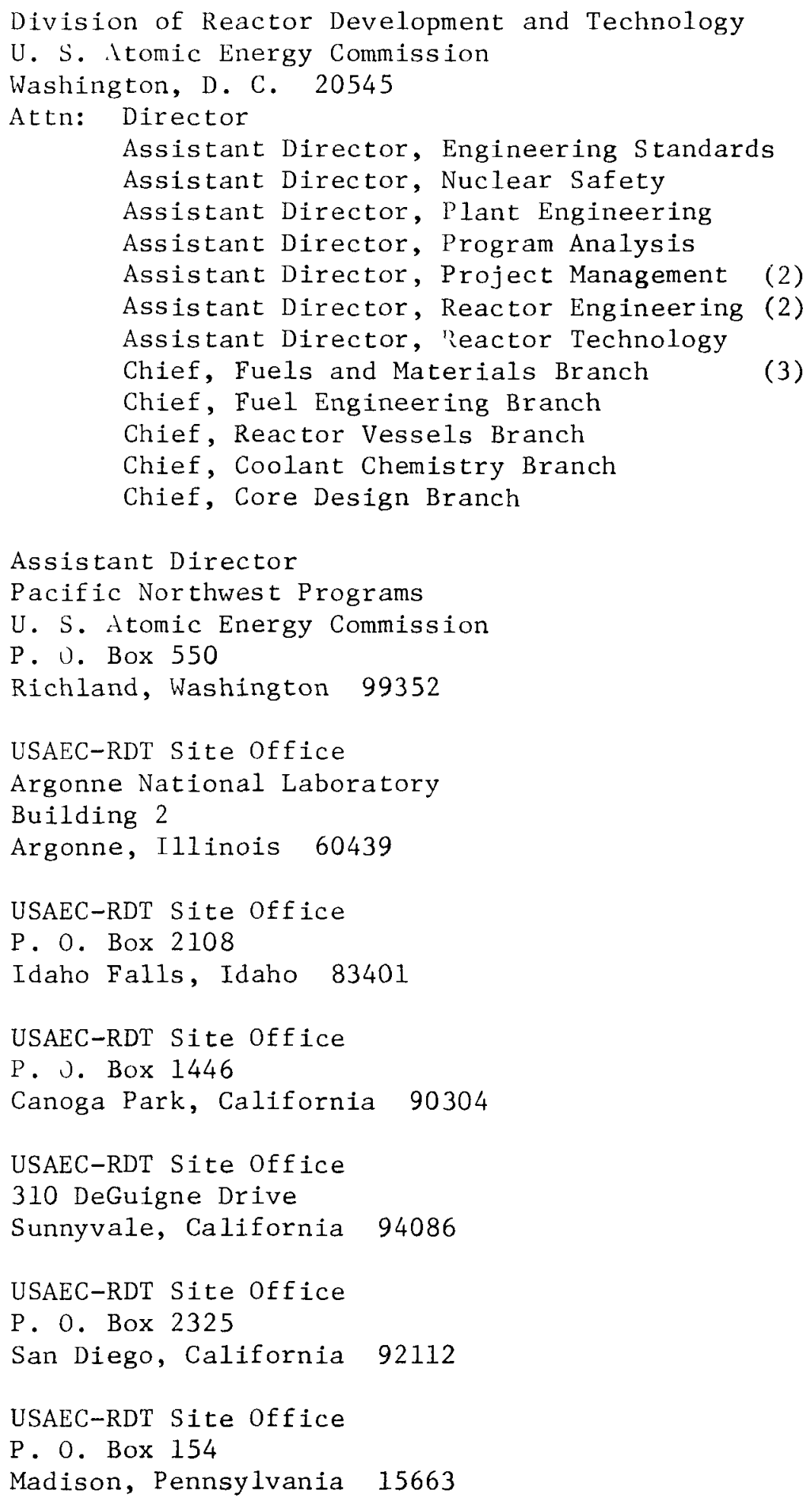


Director, Nuclear Development Center The Babcock and Wilcox Company

Atomic Energy Division

Lynchburg, Virginia 24501

Manager, Plutonium Chemistry and Ceramics Fuels Development Nuclear Materials and Equipment Corporation

Leechburg, Pennsylvania 15656

Manager, Sodium Reactor Technology

General Electric Company

Breeder Reactor Development Operation

310 DeGuigne Drive

Sunnyvale, California 94086

Manager, Nuclear Laboratories

Combustion Engineering, Inc.

Nuclear Division

Prospect Hill Road

Windsor, Connecticut 06095

Laboratory Assistant Director

Gulf Energy \& Environmental Systems, Inc.

P. O. Box 608

San Diego, California 92112

Manager, Research

United Nuclear Corporation

Research and Engineering Center

Grasslands Road

Elmsford, iNew York 10523

Head, Fuels and Materials

Atomic Power Development Associates

1911 First Street

Detroit, Michigan 48226

K-2 Group Leader

Reactor Division

Los Alamos Scientific Laboratory

P. O. Box 1663

Los Alamos, New Mexico 87544

Irradiations Coordinator

EBR-II Project

Argonne National Laboratory

P. O. Box 1096

Idaho Falls, Idaho 83401

Director

Vallecitos Nuclear Center

General Electric Company

P. O. Box 846

Pleasanton, California 94566 
Experiment Manager

EBR-II Project

Argonne National Laboratory

9700 South Cass Avenue

Argonne, Illinois 60430 